\title{
The Frankia alni Symbiotic Transcriptome
}

\author{
Nicole Alloisio, ${ }^{1}$ Clothilde Queiroux, ${ }^{1}$ Pascale Fournier, ${ }^{1}$ Petar Pujic, ${ }^{1}$ Philippe Normand, ${ }^{1}$ David Vallenet, ${ }^{2}$ \\ Claudine Médigue, ${ }^{2}$ Masatoshi Yamaura, ${ }^{3}$ Kentaro Kakoi, ${ }^{3}$ and Ken-ichi Kucho ${ }^{3}$ \\ ${ }^{1}$ Université de Lyon, Lyon, France; Université Lyon 1, Lyon, France; CNRS, UMR 5557, Ecologie Microbienne, Villeurbanne, \\ F-69622, France; ${ }^{2}$ CNRS UMR8030, CEA/DSV/IG/Genoscope/LGC, 2, rue Gaston Crémieux, 91057 Evry Cedex, France; \\ ${ }^{3}$ Graduate School of Science and Engineering, Kagoshima University, Korimoto 1-21-35, Kagoshima 890-0065, Japan
}

Submitted 22 October 2009. Accepted 12 January 2010.

The actinobacteria Frankia spp. are able to induce the formation of nodules on the roots of a large spectrum of actinorhizal plants, where they convert dinitrogen to ammonia in exchange for plant photosynthates. In the present study, transcriptional analyses were performed on nitrogen-replete free-living Frankia alni cells and on Alnus glutinosa nodule bacteria, using whole-genome microarrays. Distribution of nodule-induced genes on the genome was found to be mostly over regions with high synteny between three Frankia spp. genomes, while nodule-repressed genes, which were mostly hypothetical and not conserved, were spread around the genome. Genes known to be related to nitrogen fixation were highly induced, nif (nitrogenase), hup2 (hydrogenase uptake), suf (sulfur-iron cluster), and shc (hopanoids synthesis). The expression of genes involved in ammonium assimilation and transport was strongly modified, suggesting that bacteria ammonium assimilation was limited. Genes involved in particular in transcriptional regulation, signaling processes, protein drug export, protein secretion, lipopolysaccharide, and peptidoglycan biosynthesis that may play a role in symbiosis were also identified. We also showed that this Frankia symbiotic transcriptome was highly similar among phylogenetically distant plant families Betulaceae and Myricaceae. Finally, comparison with rhizobia transcriptome suggested that $F$. alni is metabolically more active in symbiosis than rhizobia.

Frankia spp. are among the very few soil microbes able to modify the plant hormonal balance, induce tissue differentiation, and establish nitrogen-fixing structures on the roots of higher plants belonging to eight dicotyledonous families collectively called actinorhizals (Benson and Silvester 1993). Despite marked morphological differences in nodules between actinorhizal and leguminous plants (Pawlowski and Bisseling 1996), the molecular phylogeny of these two groups of plants that engage in root symbioses showed they all belong to a single lineage, the Rosid I clade (Soltis et al. 1995), suggesting the existence of conserved determinants, such as the SymRK kinase that is essential to establish nodulation with Frankia spp. (Gherbi et al. 2008; Markmann et al. 2008).

Microarray data are available in the National Center for Biotechnology Information Gene Expression Omnibus database under accession number GSE18190.

Corresponding author: P. Normand; Telephone: +33 4724316 76; Fax: +334262344 68; E-mail: philippe.normand@univ-lyon1.fr

* The e-Xtra logo stands for "electronic extra" and indicates that nine supplementary tables and one supplementary figure are available online.
Although both bacteria establish root nodule symbiosis with plants, Frankia spp. show many physiological features different from rhizobia. Frankia spp. fix nitrogen under free-living (FL) conditions (Benson and Silvester 1993), while most rhizobia do not. Under FL nitrogen (N)-fixing conditions and under symbiotic conditions with most hosts, Frankia spp. differentiate into unique structures called vesicles (Parsons et al. 1987). Nitrogen fixation occurs in these vesicle cells, in which nitrogenase is protected from oxygen by multilayered hopanoid lipid envelopes surrounding the cell. This is in marked contrast to rhizobia, in which leghemoglobin supplied by the host plant controls oxygen concentration (Ott et al. 2005).

The genomes of three Frankia strains have recently been determined and were shown to have undergone multiple lateral transfers, duplications, and losses of genes (Normand et al. 2007b). These genomes have, nevertheless, retained a core of about 3,000 genes representing 35 to $51 \%$ of identified open reading frames, depending on the strain, some of which are expected to be responsible for symbiosis (Normand et al. 2007a). However, no significant symbiotic island or canonical nod gene homologs of rhizobia were identified in the genomes, confirming the results of Ceremonie and associates (1998), who had found no genetic complementation by Frankia alnia DNA of Rhizobium nodB and nodC mutants, leaving unanswered the question of which genes were involved in the symbiosis establishment and functioning.

In rhizobia, genes involved in symbiosis were identified by mutagenesis and most of them are clustered either on symbiotic plasmids (Galibert et al. 2001; Gonzalez et al. 2003; Mavingui et al. 2002; Young et al. 2006) or in symbiotic islands on the chromosome (Gottfert et al. 2001; Kaneko et al. 2002). Genes contained in the clusters have significantly lower GC content than those in other parts of the genome, suggesting a foreign origin. Symbiotic plasmids occur in bacteria belonging to genera Rhizobium (Mavingui et al. 2002; Gonzalez et al. 2003; Young et al. 2006) and Sinorhizobium (Galibert et al. 2001) and vary in size from 0.4 to $1.4 \mathrm{Mb}$. Symbiotic islands are found in species of genera Mesorhizobium (Kaneko et al. 2000), Bradyrhizobium (Kaneko et al. 2002) and Azorhizobium (Lee et al. 2008), which are around $0.6 \mathrm{Mb}$ in size except that of Azorhizobium caulinodans, which is quite small $(0.09 \mathrm{Mb})$. Symbiotic islands are flanked by tRNA sequences, suggesting that they have been inserted in the chromosome by site-specific integration with phage integrase. These structures are reminiscent of what is known to occur in bacterial pathogens and may arise due to lateral gene transfer (LGT) or due to protein synthesis optimized by gene clustering (Bloch and Rode 1996; Claros et al. 2006; Kers et al. 2005; Nano et al. 2004). Most often, the symbiotic plasmid or island region comprises the nif and nod genes, the dicarboxylate transporter $d c t A$, as well as a few hypothetical and strain-spe- 
cific genes (Perret et al. 1991); it can also be transferred laterally as a symbiotic island (Sullivan and Ronson 1998). Other Rhizobium genes that have been shown or suspected to play a role in nodulation are those involved in the synthesis of exopolysaccharides (Gonzalez et al. 1996), lipopolysaccharides (LPS) (Lerouge and Vanderleyden 2002), capsular polysaccharides (KPS) (Parada et al. 2006), cytokinins (Cooper and Long 1994), and 5-aminoimidazole-4-carboxamide riboside, a purine synthesis intermediate (Newman et al. 1994). In any case, a Nod factor-based mechanism may not be universal, as it was recently shown in photosynthetic Bradyrhizobium strains that no canonical nod genes were present in the genome (Giraud et al. 2007).

Some Frankia genes are known or at least postulated to be involved in symbiotic interactions. They are those coding for nitrogenase, the enzyme at the core of nitrogen fixation (Lundquist and Huss-Danell 1991), uptake hydrogenase (Sellstedt and Mattsson 1994), and hopanoid lipids biosynthesis genes (Berry et al. 1993). Some rare metabolites have been heralded as Frankia species specific, such as the sugar 2-Omethyl-D-mannose found in all strains assayed (Mort et al. 1983) and the aromatic phenylacetate fpind in F. alni (Hammad et al. 2003). They may be a part of the molecular dialogue between Frankia spp. and their hosts in parallel with other plantactive compounds. The first such compounds described were the plant hormones cytokinin (Stevens and Berry 1988) and three auxin-like indole derivatives (Berry et al. 1989). Later, a small (molecular weight $<3,000$ ) heat-stable water-soluble compound present in the supernatant of Frankia culture medium that induced root-hair branching was described (Van Ghelue et al. 1997) and shown to probably contain $N$-acetyl-Dglucosamine and to be susceptible to enzymatic attack (Ceremonie et al. 1999). Finally, phenylacetate also detected in the supernatant of Frankia culture medium (Hammad et al. 2003) has auxinic activity as well as cell-differentiating activity and is also an antimicrobial and antifungal molecule (Hwang et al. 2001).

DNA arrays have been used to identify modifications of gene-expression patterns such as those occurring in Sinorhizobium (Barnett et al. 2004; Becker et al. 2004; Capela et al. 2006), Mesorhizobium (Uchiumi et al. 2004), Bradyrhizobium (Chang et al. 2007; Hauser et al. 2007; Pessi et al. 2007) and Azorhizobium (Tsukada et al. 2009) species as they enter symbiosis. Such studies typically detect those genes previously known through classical genetic approaches to be involved as well as other structural or regulatory genes. However, this technique is especially promising in nongenetically workable bacteria such as Mycobacterium leprae, in which it allowed confirmation of the catabolic utilization of fatty acids (Williams et al. 2004) or the study of the regulatory role for noncoding pseudogenes (Suzuki et al. 2006) and holds promise for the study of numerous Mycoplasma and Rickettsia species and other unisolated microbial pathogens and symbionts.

Given the present lack of classical genetic tools to identify symbiotic genes, Frankia genomes were sequenced and annotated to determine their structure, to identify putative genes in- volved in symbiosis, and to allow the investigation of symbiosis by large-scale tools such as proteomics or transcriptomics. In the present study, we report for the first time on expression profiling of 6,607 predicted genes of $F$. alni $\mathrm{ACN} 14 \mathrm{a}(\mathrm{ACN})$. Transcript levels of these genes were monitored under N-replete FL conditions and in Alnus glutinosa nodule bacteria to identify genes differentially expressed in symbiosis. Two similar array experiments performed independently in our two laboratories were first compared to identify strongly significant differential genes. Then, these results were further strengthened by transcriptomic analysis in three other tree species, $A$. nepalensis, Morella rubra, and Myrica gale. We also tried to distinguish nitrogen fixation-related genes from nodulation-related genes by comparing these results with transcriptomic results of cells grown under N-fixing FL conditions. Finally, an in silico comparison of the transcriptomic analysis with rhizobia was performed.

\section{RESULTS AND DISCUSSION}

\section{Gene expression pattern in A. glutinosa nodule as compared with FL bacteria.}

Analysis overview. To address gene expression changes of $F$. alni ACN in the symbiotic state, we compared transcript levels between young nodules ( 3 to 4 weeks old) and cultured cells grown in N-replete minimal medium. Two data sets (A and B), obtained in our two laboratories with similar experimental conditions, were analyzed using a stringent statistical test. In data set A, 871 genes showed a differential expression in symbiosis vs. in vitro N-replete FL cells (Supplementary Table 1) compared with 457 genes in data set B (Supplementary Table 2). The lower number of differential genes in data set $\mathrm{B}$ was related to lower fold change (FC), up to 396 and 149 for data sets $\mathrm{A}$ and $\mathrm{B}$, respectively. From these two differential expression gene lists, we extracted i) 292 'common' genes (Supplementary Table 3), with 166 genes upregulated and 126 genes downregulated in both data sets (Table 1) and ii) two genes displaying opposite regulation in the two data sets (FRAAL0302, encoding an antioxidant protein, and FRAAL1882, encoding a putative small heat-shock protein), which were discarded. Interestingly, these two discordant regulations result essentially from differences between fluorescent array signals under $\mathrm{N}$ replete FL conditions but not in nodules, illustrating that the reference condition has a major effect on differential expression results (Supplementary Table 4). We concluded that the expression change in nodule of these 292 common genes was strongly significant and that they were very likely to play some roles in symbiosis. In this paper therefore, we will review and discuss mainly the putative symbiotic role of the common genes and consider genes differentially expressed in only one data set if they reinforce the claim made by common genes, e.g., six out of eight genes belonging to the ATP synthase cluster (FRAAL5930 to 5937) were up-regulated in the two data sets, whereas the two remaining genes FRAAL5934 and 5937 were up-regulated only in one of the two data sets, A or

Table 1. Overview of Frankia alni ACN14a symbiotic transcriptome analyses

\begin{tabular}{|c|c|c|c|}
\hline Comparison & Differential $^{\mathrm{a}}$ & Upregulated $^{\text {b }}$ & Downregulated $^{c}$ \\
\hline Alnus glutinosa nodules vs. N-replete free-living (FL) cells (data set A) & 871 & 415 & 456 \\
\hline A. glutinosa nodules vs. N-replete FL cells (data set B) & 457 & 265 & 192 \\
\hline Genes differential in data sets $\mathrm{A}$ and $\mathrm{B}$ & 292 & 166 & 126 \\
\hline Genes differential in the four tree species ${ }^{\mathrm{d}}$ & 223 & 117 & 106 \\
\hline
\end{tabular}

a Total number of differentially expressed genes (up- and downregulated).

b Number of genes with increased expression in nodules.

${ }^{\mathrm{c}}$ Number of genes with decreased expression in nodules.

${ }^{\mathrm{d}}$ A. glutinosa, A. nepalensis, Myrica gale, and Morella rubra. 
B. Indeed, it must be kept in mind that those genes were judged as nondifferential in one data set, but $\mathrm{FC}$ or $P$ value could be on the borderline.

Chromosomal distribution of the genes that are up-regulated in nodules was evaluated (Fig. 1). Nodule-induced genes are separately clustered in several small chromosomal regions, showing that $F$. alni does not contain a symbiotic island consisting of numerous nodule-induced genes, which was found in rhizobia such as Bradyrhizobium japonicum (Pessi et al. 2007) and Mesorhizobium loti (Uchiumi et al. 2004). However, they are mostly located in the first and last thirds of the linearized genome, which correlates with the high synteny in these regions, suggesting that those genes are highly conserved in the three sequenced Frankia genomes (ACN, EAN1pec (EAN), and $\mathrm{CcI} 3$ ) (Normand et al. 2007a). In contrast, downregulated genes are more homogenously spread around the chromosome. Table 2 shows correlation between conservation of genes and differential expression. About $40 \%$ of ACN genes contained in genome or microarray were conserved in the other two Frankia genomes (EAN and CcI3), thus these genes constitute the Frankia conserved core. More than $66 \%$ of genes were conserved in upregulated genes, whereas the percentage in downregulated genes was similar to that in the genome $(\leq 44 \%)$, confirming the results shown in Figure 1 that noduleactivated genes are mostly conserved. Genes crucial for symbiosis would be contained in the regions with high conservation and induction.

Assignment of functional clusters of orthologous gene (COG) classes (Tatusov et al. 2001) on ACN genes showed that differentially expressed genes were overrepresented in classes $\mathrm{J}$ (translation, ribosomal structure, and biogenesis) and $\mathrm{C}$ (energy production and conversion) and were mostly upregulated (Fig. 2). Differentially expressed genes without COG function account for about $25 \%$, a proportion similar to that of the whole genome, and are predominantly down-regulated. This last feature suggests that most downregulated genes encode nonessential functions.

Nitrogen fixation and closely related functions. Among the 292 common genes showing a differential expression in the two data sets, 53 genes had FC values $>10$ in one or both data

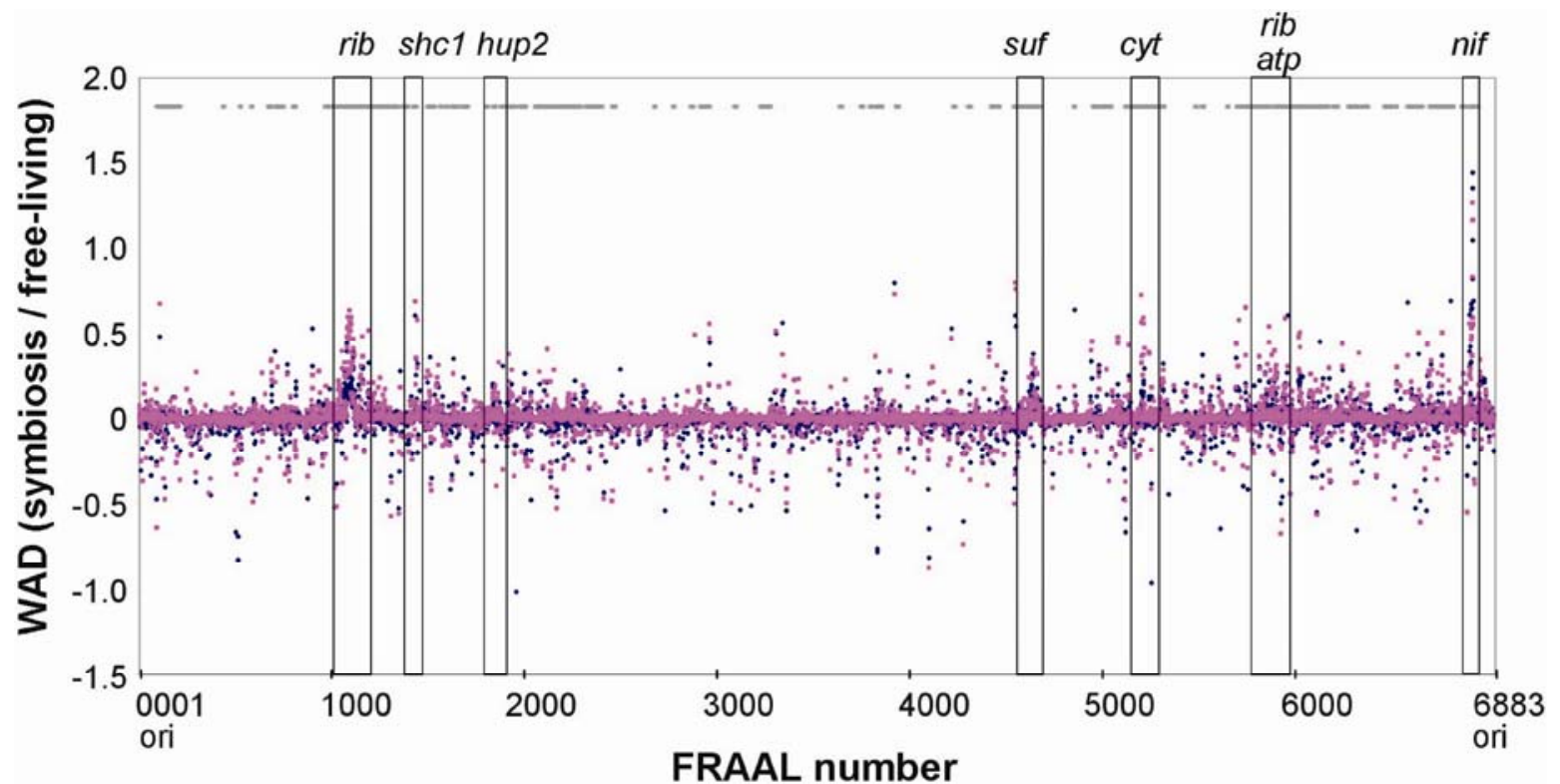

Fig. 1. Expression values in nodules vs. N-replete free-living (FL) cells for each gene plotted against gene number FRAAL order on the linearized Frankia alni genome with the chromosome replication origin (ori) at both ends. We used weighted average difference (WAD) values ( $y$ axis), which is a $\log _{10}$-transformed fold change weighted by the absolute expression level (Kadota et al. 2008) to improve visualization of regions with differential gene expression. Data from experiments A and B are indicated by blue and pink dots, respectively. The positions of seven upregulated clusters are shown. The rib-encoding ribosomal proteins (FRAAL1064 to 1115; FRAAL5779 to 5812), the shcl-encoding hopanoid biosynthesis enzymes (FRAAL1426 to 1434), the hup2-encoding uptake hydrogenases (FRAAL1822 to 1832), the suf-encoding sulfur-iron cofactor assembly proteins (FRAAL4557 to 4563), the cyt-encoding cytochrome c oxidases (FRAAL5109 to 5123), the atp-encoding ATP synthases (FRAAL5930 to 5937), and the nif-encoding nitrogenases (FRAAL6797 to 6814). Syntenic regions are indicated by gray dots at the top and defined by the presence of at least five consecutive genes in the three strains (ACN, EAN, and CcI3) showing $50 \%$ amino acid identity over $80 \%$ of the length of the smaller gene.

Table 2. Absolute number and percentage of the conserved genes in various subsets of genes ${ }^{\mathrm{a}}$

\begin{tabular}{|c|c|c|c|c|c|c|c|c|c|}
\hline \multirow[b]{2}{*}{ Genes } & \multirow[b]{2}{*}{ Total } & \multirow[b]{2}{*}{ Conserved } & \multirow[b]{2}{*}{$\%$} & \multicolumn{3}{|c|}{ Upregulated } & \multicolumn{3}{|c|}{ Downregulated } \\
\hline & & & & Total & Conserved & $\%$ & Total & Conserved & $\%$ \\
\hline ACN genome & 6,723 & 2,824 & 42 & $\ldots$ & $\ldots$ & $\ldots$ & $\ldots$ & $\ldots$ & $\ldots$ \\
\hline Microarray & 6,607 & 2,815 & 43 & & & $\ldots$ & & $\ldots$ & $\ldots$ \\
\hline Differential $(A)^{b}$ & 871 & 451 & 52 & 415 & 274 & 66 & 456 & 177 & 39 \\
\hline Differential $(B)^{c}$ & 457 & 279 & 61 & 265 & 200 & 75 & 192 & 79 & 41 \\
\hline Common genes ${ }^{\mathrm{d}}$ & 292 & 183 & 63 & 166 & 127 & 77 & 126 & 56 & 44 \\
\hline
\end{tabular}

${ }^{a}$ Number of genes conserved in three Frankia genomes (ACN, CcI3, and EAN) at a threshold level of $40 \%$ amino acid identity over $80 \%$ of the length of the smaller gene. Bold characters indicate higher percentage of conserved genes.

${ }^{\mathrm{b}}$ Genes differentially expressed in data set A.

${ }^{\mathrm{c}}$ Genes differentially expressed in data set B.

${ }^{\mathrm{d}}$ Genes differentially expressed in both data sets A and B. 
sets (Table 3). As expected, the most highly induced genes were the nif genes, especially the structural nifHDK genes encoding nitrogenase (FC up to 396), which confirms the usefulness of the transcriptome approach. The cluster of nif genes containing 15 genes (FRAAL6800 to 6814), three of which are hypothetical, behaved coherently as all genes were up-regulated (Fig. 3A). This operon is bordered on its left side by two genes encoding ferredoxin oxidoreductase subunits and a gene encoding ferredoxin (FRAAL6797 to 6799) which are all highly upregulated (Table 3; Fig. 3A), suggesting a role in the electron transport pathway to nitrogenase, as it was shown in Bradyrhizobium japonicum (Hauser et al. 2007). Synteny of those genes observed in the genomes of two other Frankia strains supports this hypothesis (Table 3; Fig. 3A). A second conserved ferredoxin gene ( $f d x l$, FRAAL3855), localized away from the nif operon, was also strongly induced, being the fifth top-scoring gene (Table 3 ). This gene could also contribute to nitrogen fixation, since several ferredoxins in $B$. japonicum are involved in nitrogen fixation (Hauser et al. 2007). On the other hand, three other ferredoxin genes (FRAAL1469, FRAAL1995, FRAAL6126) were not induced in nodule. FRAAL1673, encoding a putative molybdenum-binding protein, was induced in nodules (Table 3) and has orthologs in EAN and CcI3. Its gene product could supply molybdenum cofactor for nitrogenase complex biosynthesis.

The second upregulated cluster (FC up to 21.5) encodes uptake hydrogenase 2 (Hup2) (FRAAL1822 to 1832), which is assumed to convert hydrogen produced by nitrogenase into protons and electrons (Table 3; Fig. 3B) (Sellstedt and Mattsson 1994). Conversely, another hydrogenase cluster, hupl (FRAAL2388 to 2400), showed no significant upregulation. Similar results were reported by Leul and associates (2007), who analyzed transcript level of uptake Hup1 and Hup2, using quantitative real-time polymerase chain reaction (PCR), and found that the latter one is more-expressed in symbiosis whereas the former is more-expressed in FL cells. Like the nif cluster, the hup 2 cluster is present in the other two Frankia strains, even though it has been reshuffled in EAN through
LGT (Fig. 3B) (Leul et al. 2009). These results support the suggestion that uptake Hup2 is related to nitrogen fixation.

The third upregulated cluster (FC up to 11.1) contained sufBCDESU genes (FRAAL4557 to 4563) that are involved in iron-sulfur (Fe-S) cluster formation (Fig. 3C). This fits the strong requirement for $\mathrm{Fe}-\mathrm{S}$ clusters of key nitrogen fixationrelated enzymes such as nitrogenase and uptake Hup2. In an Azorhizobium caulinodans mutant with a disruption in the sufS gene, nodules produced lacked nitrogen-fixing ability (Suzuki et al. 2007).

Vesicle hopanoid membrane. Formation of vesicles is a unique feature in the microbial world. These specialized nitrogen-fixing cells, which differentiate under nitrogen-limiting conditions, provide a barrier for up to $80 \%$ oxygen (Parsons et al. 1987) and, thus, prevent the fragile nitrogenase from oxygen inactivation. Oxygen diffusion is tightly controlled by the vesicle envelope made up of several tens of hopanoid lipid layers consisting of the relatively common bacteriohopanetetrol (BHT) and its unique phenylacetate ester (PAA-BHT) (Berry et al. 1993). Hyphae, on the contrary, are not surrounded by this multilayered lipid envelope and do not contain the PAABHT; however, they contain BHT, although probably less than in large symbiotic vesicles (Nalin et al. 2000). In that sense, genes involved in biosynthesis of BHT and BHT-PAA can be essential for nitrogen fixation and, thus, to symbiosis. These genes encode enzymes belonging to the methyl-erythritol (nonmevalonate) isopentenyl diphosphate and hopanoid pathways. Several of them were up-regulated, $d x$ s (FRAAL2088) and $i s p G$ (FRAAL5772) involved in isopentenyl diphosphate biosynthesis as well as idi (FRAAL6504) and a putative squalene/phytoene dehydrogenase (FRAAL1430) involved in hopanoid biosynthesis. The last gene is localized in the shcl cluster (FRAAL1428-1433) containing the major genes leading to hopanoid biosynthesis such as those encoding squalene synthase and squalene-hopene cyclase (Shc) 1; all these genes were up-regulated (Fig. 3D). In contrast, the second shc gene (shc2, FRAAL2491), which is not contained in the shcl cluster, did not show differential expression change. This result

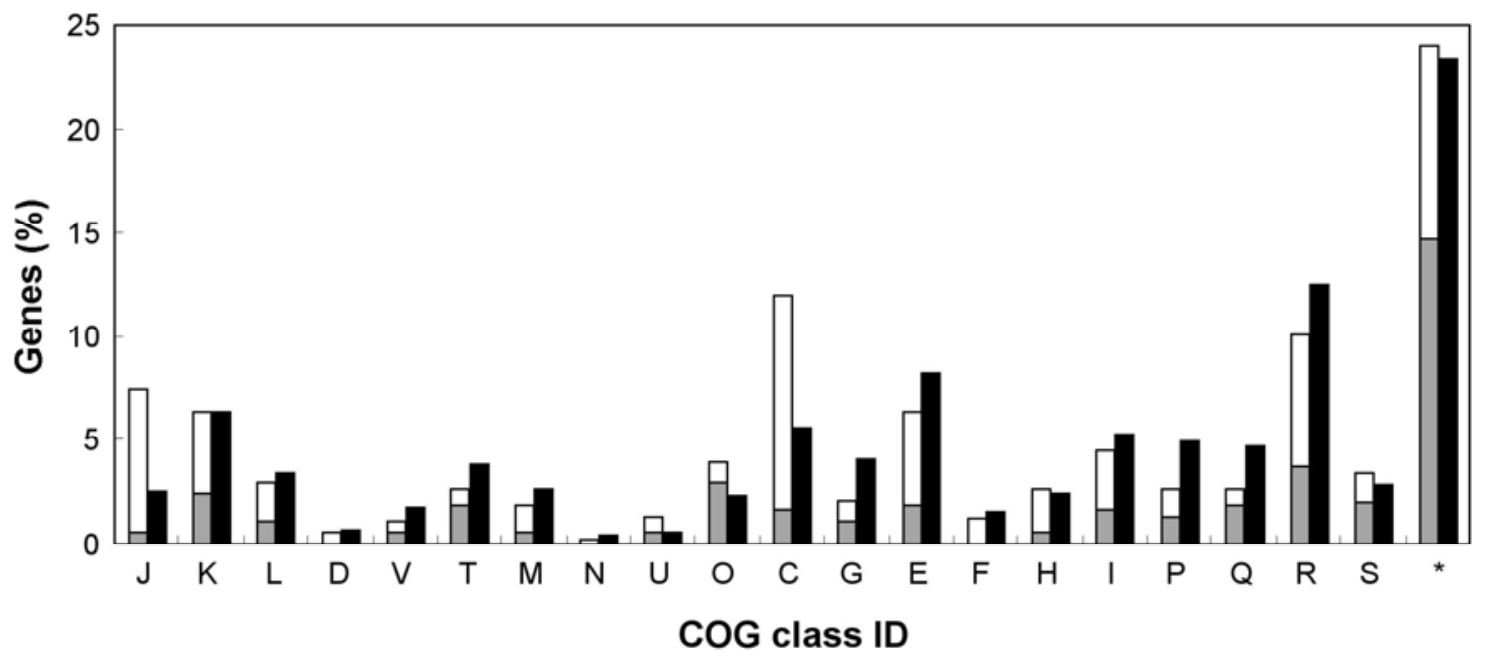

Fig. 2. Differentially expressed genes in nodules vs. N-replete free-living (FL) cells categorized by functional clusters of orthologous genes (COG) classes (Tatusov et al. 2001). Percentages are calculated by dividing the number of up- (white) or downregulated (gray) genes in each class by the total number of differentially expressed genes. For comparison, black columns indicate the percentage of genes of ACN14a genome in each COG class. Differentially expressed genes without COG function (*) account for about $25 \%$, as in the genome, and are predominantly down-regulated. In contrast, differentially expressed genes belonging to $\mathbf{J}$ and $\mathrm{C}$ classes are overrepresented and mostly upregulated. COG identification: $\mathbf{J}=$ translation, ribosomal structure, and biogenesis; $\mathrm{K}=$ transcription; $\mathrm{L}=$ replication, recombination, and repair; $\mathrm{D}=$ cell cycle control, cell division, chromosome partitioning; $\mathrm{V}=$ defense mechanisms; $\mathrm{T}=$ signal transduction mechanisms; $\mathrm{M}=$ cell wall/membrane/envelope biogenesis; $\mathrm{N}=$ cell motility; $\mathrm{U}=$ intracellular trafficking, secretion, and vesicular transport; $\mathrm{O}=$ posttranslational modification, protein turnover, chaperones; $\mathrm{C}=$ energy production and conversion; $\mathrm{G}=$ carbohydrate transport and metabolism; $\mathrm{E}=$ amino acid transport and metabolism; $\mathrm{F}=$ nucleotide transport and metabolism; $\mathrm{H}=$ coenzyme transport and metabolism; $\mathrm{I}=$ lipid transport and metabolism; $\mathrm{P}=$ inorganic ion transport and metabolism; $\mathrm{Q}=$ secondary metabolites biosynthesis, transport, and catabolism; $\mathrm{R}=$ general function prediction only; $\mathrm{S}=$ function unknown. 
suggests that the $s h c 2$ gene is not a gene essential for nitrogen fixation as previously mentioned, based on its absence in the $\mathrm{CcI} 3$ genome. Furthermore, we found that two genes (FRAAL1426 and 1427) preceding the shcl cluster and encoding a hypothetical protein and a putative short-chain dehydro- genase/oxydoreductase (Fig. 3D) were among the most highly induced genes (Table 3). Interestingly, this short-chain dehydrogenase and Shc1 belong to the core Frankia secretome, which consists of 161 secreted proteins conserved in the three Frankia strains (Mastronunzio et al. 2008). Moreover, this pro-

Table 3. The 53 most highly induced genes in Alnus glutinosa nodules (fold change $>10$ in data sets A or B)

\begin{tabular}{|c|c|c|c|c|c|c|c|c|c|}
\hline \multirow[b]{2}{*}{ Gene no. ${ }^{a}$} & \multirow[b]{2}{*}{ Gene name } & \multirow[b]{2}{*}{ Product description } & \multicolumn{2}{|c|}{ Fold change $^{b}$} & \multirow[b]{2}{*}{$\mathrm{COG}^{\mathrm{d}}$} & \multirow[b]{2}{*}{ Core $^{e}$} & \multirow[b]{2}{*}{ Spe. ${ }^{f}$} & \multirow[b]{2}{*}{ Syn. ${ }^{g}$} & \multirow[b]{2}{*}{ Secr. } \\
\hline & & & $\mathbf{A}^{\mathbf{c}}$ & $\mathbf{B}^{\mathbf{c}}$ & & & & & \\
\hline FRAAL6813 & nifH & Nitrogenase reductase & 396.3 & 103.8 & $\mathrm{DP}$ & + & + & + & - \\
\hline FRAAL6812 & nifD & Nitrogenase alpha subunit & 390.3 & 149.3 & $\mathrm{C}$ & + & + & + & - \\
\hline FRAAL6811 & nifK & Nitrogenase beta subunit & 375.3 & 44.0 & $\mathrm{C}$ & + & + & + & - \\
\hline FRAAL6814 & nifV & Homocitrate synthase & 207.3 & 19.0 & $\mathrm{CE}$ & + & + & - & - \\
\hline FRAAL3855 & $f d x I$ & Ferredoxin & 161.8 & 35.2 & $\mathrm{C}$ & + & - & - & - \\
\hline FRAAL6806 & & Conserved hypothetical protein & 134.7 & 19.7 & & + & + & + & - \\
\hline FRAAL6807 & & Conserved hypothetical protein & 116.9 & 14.1 & & + & + & + & - \\
\hline FRAAL6808 & nif $X$ & NifX protein & 99.3 & 13.2 & & + & + & + & - \\
\hline FRAAL6805 & nifW & Nitrogenase stabilizing/protective protein & 98.2 & 14.4 & & + & + & + & - \\
\hline FRAAL6810 & nifE & Nitrogenase FeMo Co biosynthesis protein & 86.6 & 9.5 & $\mathrm{C}$ & + & + & + & - \\
\hline FRAAL6799 & & Ferredoxin oxidoreductase alpha subunit & 62.8 & 5.0 & $\mathrm{C}$ & + & - & + & - \\
\hline FRAAL6797 & & Ferredoxin & 60.2 & 28.4 & $\mathrm{C}$ & + & - & + & - \\
\hline FRAAL6803 & nifB & FeMo Co biosynthesis protein & 51.2 & 6.4 & $\mathrm{R}$ & + & + & + & - \\
\hline FRAAL6801 & & Putative molybdopterin biosynthesis protein HesA & 48.1 & 5.9 & $\mathrm{H}$ & + & + & + & + \\
\hline FRAAL6486 & groL & Chaperone Hsp60 & 40.3 & 7.2 & $\mathrm{O}$ & + & - & - & - \\
\hline FRAAL6804 & nifZ & NifZ protein & 39.7 & 4.7 & $\mathrm{C}$ & + & + & + & - \\
\hline FRAAL3254 & & Hypothetical protein & 38.8 & 14.4 & $\mathrm{~S}$ & + & + & - & - \\
\hline FRAAL6816 & & Hypothetical protein & 37.2 & 14.5 & $\mathrm{E}$ & + & + & + & - \\
\hline FRAAL6798 & & Ferredoxin oxidoreductase beta-subunit & 28.2 & 4.6 & $\mathrm{C}$ & + & - & + & - \\
\hline FRAAL3287 & & Conserved hypothetical protein & 24.9 & 8.5 & & - & - & - & - \\
\hline FRAAL4419 & & Hypothetical protein & 22.4 & 3.6 & & - & - & - & - \\
\hline FRAAL4403 & & Putative RNA helicase & 22.3 & 3.9 & LRJK & + & - & + & - \\
\hline FRAAL1830 & hupS2 & [NiFe] uptake hydrogenase small subunit & 21.5 & 3.4 & $\mathrm{C}$ & - & - & - & - \\
\hline FRAAL3922 & & Putative export protein & 20.6 & 5.2 & RU & - & - & - & - \\
\hline FRAAL5232 & & Putative integration host factor-like protein & 18.2 & 6.1 & $\mathrm{~L}$ & + & - & + & - \\
\hline FRAAL1829 & hupL2 & [NiFe] uptake hydrogenase large subunit & 18.0 & 2.8 & $\mathrm{C}$ & - & - & + & - \\
\hline FRAAL1673 & & Putative Mo binding protein & 17.8 & 3.8 & GR & + & - & - & - \\
\hline FRAAL4897 & & 1-Acylglycerol-3-phosphate $O$-acyltransferase & 16.1 & 9.2 & I & + & - & - & - \\
\hline FRAAL1426 & & Hypothetical protein & 15.3 & 17.6 & & - & - & - & - \\
\hline FRAAL1831 & hypA2 & Hydrogenase nickel incorporation protein & 15.0 & 2.9 & $\mathrm{R}$ & - & - & + & - \\
\hline FRAAL4147 & $c t a D$ & Cytochrome c oxidase & 14.3 & 6.2 & $\mathrm{C}$ & + & - & - & - \\
\hline FRAAL5516 & & Putative AAA family Cell division control ATPase & 14.2 & 3.4 & OKR & - & - & - & - \\
\hline FRAAL4858 & & Putative LuxR-family transcriptional regulator & 13.7 & 8.3 & $\mathrm{~K}$ & + & - & - & - \\
\hline FRAAL1156 & sucC & Succinyl-CoA synthetase beta subunit & 13.6 & 10.5 & CI & + & - & + & - \\
\hline FRAAL4896 & & Putative multidrug efflux transporter & 13.3 & 9.8 & RUV & + & - & + & - \\
\hline FRAAL5724 & & Putative RNA polymerase ECF sigma factor & 12.2 & 9.1 & $\mathrm{~K}$ & + & - & + & - \\
\hline FRAAL6541 & & Hypothetical protein & 12.1 & 16.0 & & - & - & - & - \\
\hline FRAAL1155 & & Putative serine/threonine protein kinase & 12.0 & 3.7 & KLRT & + & + & + & - \\
\hline FRAAL1427 & & Putative short-chain dehydrogenase/oxidoreductase & 12.0 & 4.0 & IQR & + & - & + & + \\
\hline FRAAL0774 & & Hypothetical protein & 11.8 & 4.3 & & - & - & - & - \\
\hline FRAAL1832 & hypB2 & Hydrogenase nickel incorporation protein & 11.8 & 3.4 & EKO & + & - & + & - \\
\hline FRAAL2240 & & Hypothetical protein & 11.7 & 3.0 & & - & - & - & - \\
\hline FRAAL4471 & & Hypothetical protein & 11.6 & 17.0 & NT & - & - & - & - \\
\hline FRAAL4559 & sufS & Cysteine desulfurase/selenocysteine lyase & 11.1 & 3.7 & ER & + & - & + & - \\
\hline FRAAL2921 & & Hyp. protein (repressor-like DNA-binding domain) & 10.7 & 12.0 & & - & - & + & - \\
\hline FRAAL2922 & & Hypothetical protein & 10.7 & 14.3 & & - & - & - & - \\
\hline FRAAL4195 & & Conserved hypothetical protein & 10.6 & 3.5 & $\mathrm{FE}$ & - & - & - & - \\
\hline FRAAL1157 & sucD & Succinyl-CoA synthetase alpha subunit & 10.5 & 6.7 & $\mathrm{C}$ & + & - & + & - \\
\hline FRAAL5231 & $g m k$ & Guanylate kinase & 10.5 & 4.7 & $\mathrm{~F}$ & + & - & + & - \\
\hline FRAAL6657 & & $N$-acetylmuramoyl-L-alanine amidase (autolysin) & 10.5 & 10.5 & M & + & - & + & + \\
\hline FRAAL4560 & sufC & Fe-S cluster assembly transport protein & 10.4 & 4.5 & EPV & + & - & + & - \\
\hline FRAAL4473 & & Hypothetical protein & 9.4 & 15.3 & & - & - & - & - \\
\hline FRAAL0111 & gltA & Citrate synthase & 9.4 & 10.1 & $\mathrm{C}$ & + & - & + & - \\
\hline
\end{tabular}

${ }^{a}$ Gene numbers are ordered according to decreasing fold changes of data set A. Gene number, gene name, and product description according to the Genoscope database.

${ }^{\mathrm{b}}$ Fold change comparing nodules vs. N-replete free-living cells.

${ }^{c}$ Data sets A and B refer to similar experiments performed in our two laboratories, respectively.

${ }^{\mathrm{d}}$ Clusters of orthologous genes (COG) classes (Tatusov et al. 2001).

${ }^{\mathrm{e}}$ Core genes are conserved genes in the three strains (ACN, EAN, and CcI3) at a threshold level of $40 \%$ amino acid identity over $80 \%$ of the length of the smaller gene. $+=$ present $;-=$ absent.

${ }^{\mathrm{f}}$ Specific genes are core genes not conserved in Acidothermus cellulolyticus (NC_008578), Streptomyces avermitilis (NC_003155, NC_004719), and S. coelicolor (NC_003888, NC_003903, NC_003904) at a threshold level of 40\% amino acid identity over $80 \%$ of the length of the smaller gene.

${ }^{\mathrm{g}}$ Synteny is the presence of a group of genes in the three strains (ACN, EAN, and CcI3) having $30 \%$ amino acid identity over $80 \%$ of the length of the smaller gene, separated by no more than five intervening sequences.

${ }^{\mathrm{h}}$ Core secretome encompasses 161 conserved secreted proteins in the three strains (ACN, EAN, and CcI3) (Mastronunzio et al. 2008). 
tein is homologous to the $\mathrm{RkpH}$ protein involved in KPS production in Sinorhizobium fredii. Soybean inoculated with the S. fredii rkpH mutant showed reduced nodulation and severe symptoms of nitrogen starvation (Parada et al. 2006). On the other hand, genes involved in PAA metabolism were not upregulated in nodules. The FRAAL1434 gene coding for a putative PAA thioesterase did not show differential expression change, whereas the FRAAL3103 gene, which encodes a puta-

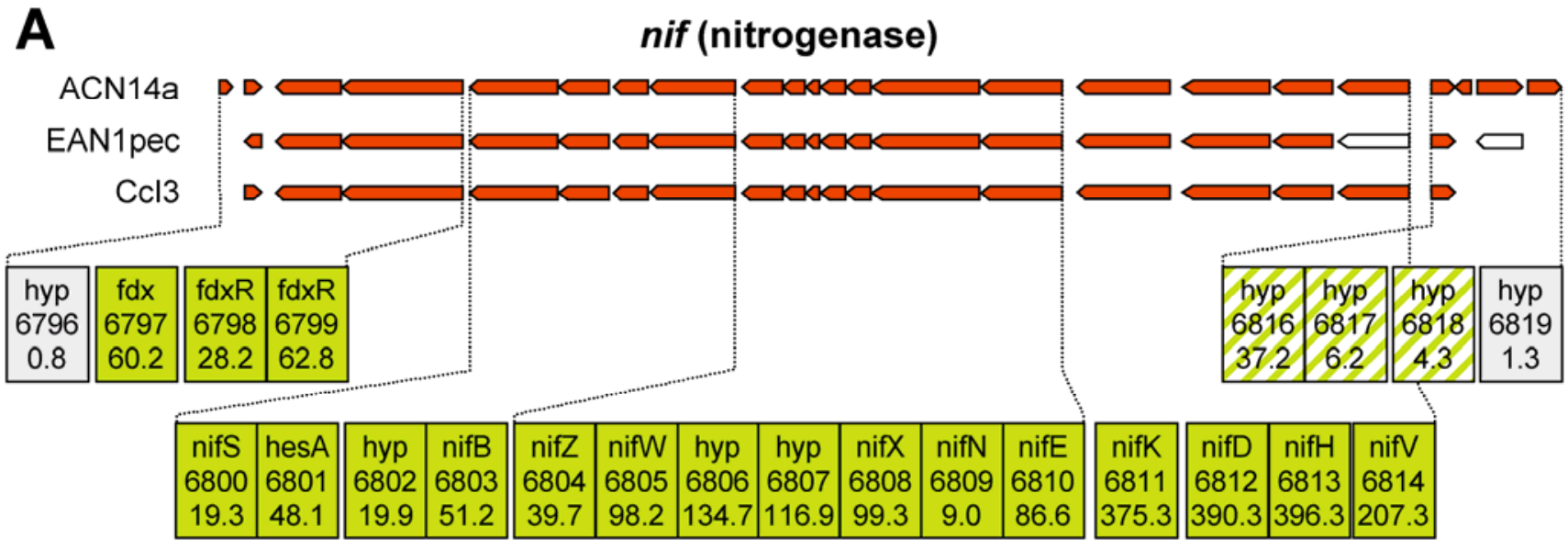

B

hup2 (hydrogenase)

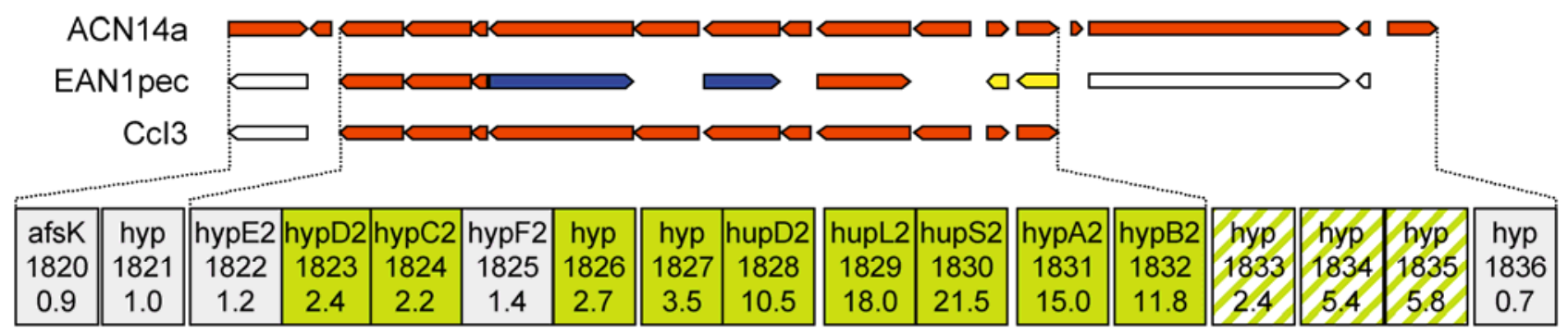

C

suf (sulfur iron cofactor)

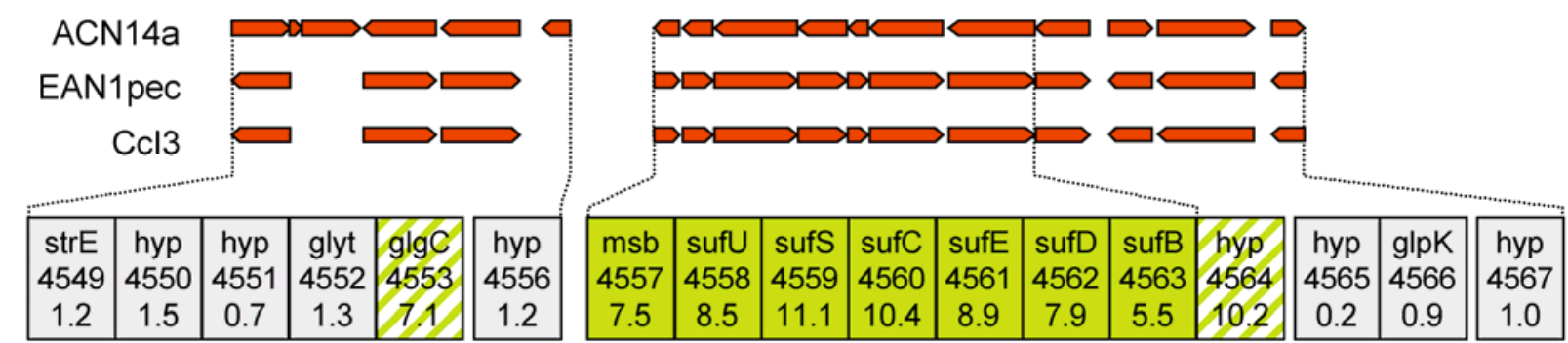

D

shc (squalene)

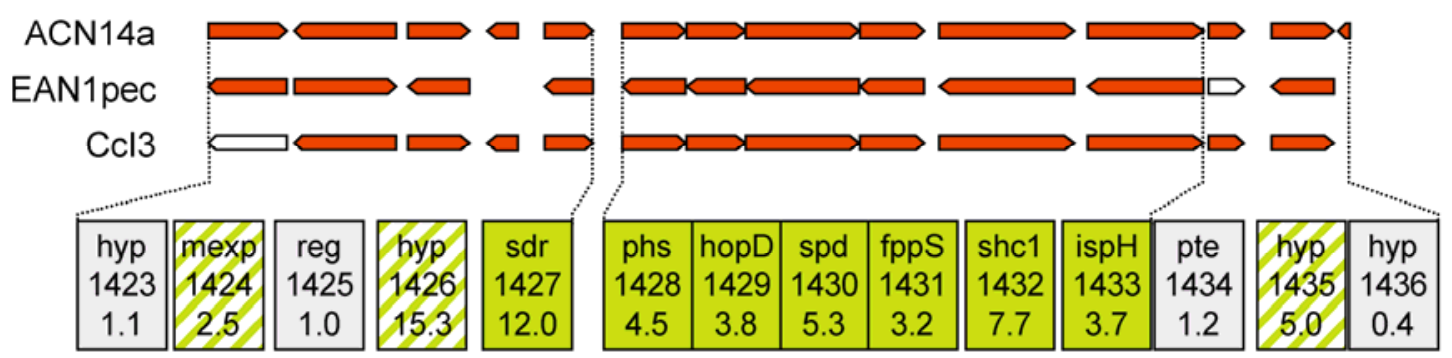

Fig. 3. Four symbiosis-related clusters upregulated in Alnus glutinosa nodules. Genes showing synteny (amino acid identity above $30 \%$ over $80 \%$ of the length of the smaller gene, separated by no more than five intervening sequences) with ACN14a and located within the corresponding cluster in each genome (EAN1pec and CcI3) are indicated by red arrows. Sets of genes that showed synteny with ACN14a but located outside of the corresponding cluster in the EAN1pec genome are blue and yellow arrows. Unfilled arrows indicate a gene whose homolog is present but outside of the cluster in each genome. In boxes below the arrows, gene names are given (top) together with their FRAAL identity number (middle) and their fold-change value (bottom). These rectangles are green when significantly upregulated in nodule, hatched when not related to the function of the cluster, and gray when not upregulated. For genes without a gene name, an abbreviation of the gene product description is given: hyp = hypothetical protein, fdxR = ferredoxin oxidoreductase, glyt = glycosyl transferase, $\mathrm{msb}=$ metal-sulfur cluster biosynthetic enzyme, mexp $=$ membrane export protein, reg $=$ TetR-family transcriptional regulator, sdr $=$ short-chain dehydrogenase/oxidoreductase, phs = phytoene synthase, $\mathrm{spd}=$ squalene/phytoene dehydrogenase, and pte $=$ phenylacetic acid thioesterase . 
tive PAA degradation protein (PaAA) and localizes away from the shcl cluster, was down-regulated. All the above genes are conserved in the three Frankia genomes, except FRAAL1426 and 3103.

Ammonium assimilation and transport. Ammonium generated from nitrogen fixation is assimilated into glutamate with glutamine synthase (GS), glutamate synthase (GOGAT), and glutamate dehydrogenase (GDH). In nodules, the $g \ln A$ gene (FRAAL5161) encoding GSI was strongly repressed (FC down to 0.061; Tables 4 and 5), whereas the glnII gene (FRAAL5163) encoding GSII was only slightly induced (about twofold; Table 5). Four other GS-encoding genes (FRAAL0678, 1887, 5165, and 6426) did not show differential expression changes (Table 5). The gdhA gene (FRAAL6693) encoding GDH displayed pronounced induction in nodule (5.4-fold; Table 5). In FL N-fixing conditions, strong repression of GSI $(g \ln A)$ was also observed $(0.2$-fold; Table 5$)$. Induction of GSII $(g \ln I I)$ expression also occurred but at a much higher level (15.1-fold; Table 5) than that occurring in nodule. Induction of GDH ( $g d h A)$ was not observed under N-fixing FL conditions (Table 5). Such a pattern of regulation in GSI, GSII, and GDH under N-fixing FL conditions was also reported in Frankia ACN and CpI1, using enzymatic and proteomic analyses (Alloisio et al. 2007; Schultz and Benson 1990). These results suggest that regulation of ammonium assimilation is different between symbiotic and FL N-fixing conditions. In addition, two out of four genes (FRAAL4964 and 4965) coding for GOGAT and one of the two ammonium transporter

Table 4. The 43 most highly repressed genes in Alnus glutinosa nodules (fold change $<0.1$ in data sets A or B)

\begin{tabular}{|c|c|c|c|c|c|c|c|c|c|}
\hline \multirow[b]{2}{*}{ Gene no. $^{\text {a }}$} & \multirow[b]{2}{*}{ Gene name } & \multirow[b]{2}{*}{ Product description } & \multicolumn{2}{|c|}{ Fold change $^{\text {b }}$} & \multirow[b]{2}{*}{$\mathrm{COG}^{\mathrm{d}}$} & \multirow[b]{2}{*}{ Core $^{e}$} & \multirow[b]{2}{*}{ Spe. ${ }^{\mathrm{f}}$} & \multirow[b]{2}{*}{ Syn. ${ }^{g}$} & \multirow[b]{2}{*}{ Secr. ${ }^{\text {h }}$} \\
\hline & & & $\mathbf{A}^{\mathbf{c}}$ & $\mathbf{B}^{\mathbf{c}}$ & & & & & \\
\hline FRAAL1946 & & Hypothetical protein & 0.009 & 0.018 & & - & - & - & - \\
\hline FRAAL3765 & & Putative sugar ABC transporter & 0.016 & 0.011 & $\mathrm{G}$ & - & - & - & - \\
\hline FRAAL3078 & & Transposase & 0.016 & 0.062 & $\mathrm{~L}$ & + & - & + & - \\
\hline FRAAL0504 & & Hypothetical protein & 0.022 & 0.037 & $\mathrm{R}$ & - & - & - & - \\
\hline FRAAL6024 & & Putative glutamate-1-semialdehyde aminotransferase & 0.025 & 0.096 & $\mathrm{EH}$ & + & + & + & - \\
\hline FRAAL3764 & & Putative sugar ABC transporter & 0.029 & 0.011 & $\mathrm{G}$ & - & - & - & - \\
\hline FRAAL5525 & & Putative acyl-CoA ligase & 0.038 & 0.047 & QI & - & - & - & - \\
\hline FRAAL6577 & hppA & Pyrophosphate-energized proton pump & 0.039 & 0.042 & CEGPR & + & - & + & - \\
\hline FRAAL1014 & & Hypothetical protein & 0.043 & 0.054 & $\mathrm{~K}$ & + & + & + & - \\
\hline FRAAL3310 & & Conserved hypothetical protein & 0.043 & 0.057 & & + & - & + & - \\
\hline FRAAL0879 & & Hypothetical protein & 0.048 & 0.056 & Q & - & - & - & - \\
\hline FRAAL0300 & & Putative $S$-adenosylmethionine transferase & 0.049 & 0.106 & QR & - & - & - & - \\
\hline FRAAL0514 & & Hypothetical protein & 0.051 & 0.037 & & + & + & + & - \\
\hline FRAAL1344 & & Hypothetical protein & 0.057 & 0.127 & & - & - & - & - \\
\hline FRAAL0891 & & Hypothetical protein & 0.058 & 0.184 & & - & - & - & - \\
\hline FRAAL0629 & & Putative acetyltranferase & 0.060 & 0.106 & $\mathrm{~J}$ & + & + & - & - \\
\hline FRAAL5161 & $g \ln A$ & Glutamine synthetase I & 0.061 & 0.279 & $\mathrm{E}$ & + & - & + & - \\
\hline FRAAL6224 & & Conserved hypothetical protein & 0.061 & 0.039 & & + & - & + & - \\
\hline FRAAL3311 & & Conserved hypothetical protein & 0.062 & 0.079 & & + & - & + & - \\
\hline FRAAL6548 & & Putative WhiB-family transcriptional regulator & 0.062 & 0.112 & & + & - & + & - \\
\hline FRAAL2150 & & Hypothetical protein & 0.064 & 0.067 & $\mathrm{~K}$ & + & + & + & - \\
\hline FRAAL3570 & & Conserved hypothetical protein & 0.068 & 0.257 & & - & - & - & - \\
\hline FRAAL0373 & & Putative acetyltransferase & 0.070 & 0.054 & $\mathrm{R}$ & - & - & - & - \\
\hline FRAAL0515 & & Hypothetical protein & 0.070 & 0.042 & & - & - & - & - \\
\hline FRAAL2313 & & Putative metallo-phospho-hydrolase & 0.073 & 0.157 & $\mathrm{R}$ & + & - & - & - \\
\hline FRAAL1286 & & Hypothetical protein & 0.076 & 0.039 & & - & - & - & - \\
\hline FRAAL4030 & & Hypothetical protein & 0.085 & 0.042 & & - & - & - & - \\
\hline FRAAL2387 & & Hypothetical protein & 0.085 & 0.078 & & + & + & - & - \\
\hline FRAAL4029 & & Conserved hypothetical protein & 0.086 & 0.042 & QO & - & - & - & - \\
\hline FRAAL3149 & atoA & Acetoacetyl-CoA transferase beta subunit & 0.093 & 0.134 & I & + & - & + & - \\
\hline FRAAL6022 & & Putative aldehyde dehydrogenase & 0.093 & 0.213 & $\mathrm{C}$ & + & - & + & - \\
\hline FRAAL3763 & & Putative sugar ABC transporter & 0.097 & 0.021 & $\mathrm{P}$ & - & - & - & - \\
\hline FRAAL0140 & & Putative helix-turn-helix-type transcriptional regulator & 0.101 & 0.089 & $\mathrm{~K}$ & - & - & - & - \\
\hline FRAAL6325 & & Hypothetical protein & 0.127 & 0.064 & & - & - & - & - \\
\hline FRAAL4664 & & Hypothetical protein & 0.130 & 0.052 & & - & - & - & - \\
\hline FRAAL0094 & & Putative serine protease & 0.137 & 0.070 & $\mathrm{O}$ & + & - & + & + \\
\hline FRAAL2120 & & Conserved hypothetical protein & 0.139 & 0.051 & $\mathrm{O}$ & + & - & + & - \\
\hline FRAAL4031 & hspl8 & Chaperone Hsp18 & 0.156 & 0.065 & $\mathrm{O}$ & - & - & - & - \\
\hline FRAAL6787 & & Conserved hypothetical protein & 0.180 & 0.075 & & - & - & - & - \\
\hline FRAAL4321 & & Hypothetical protein & 0.207 & 0.086 & $\mathrm{O}$ & + & + & + & - \\
\hline FRAAL3762 & & Putative sugar ABC transporter & 0.220 & 0.028 & EPG & + & - & - & - \\
\hline FRAAL0953 & & Hypothetical protein & 0.230 & 0.098 & & - & - & - & - \\
\hline FRAAL0021 & & Hypothetical protein & 0.295 & 0.094 & & - & - & - & - \\
\hline
\end{tabular}

${ }^{a}$ Gene numbers arbitrary ordered according to increasing fold changes of data set A (the lowest fold changes were similar in the two data sets: 0.009 and 0.011). Gene number, gene name and product description according to the Genoscope database.

${ }^{\mathrm{b}}$ Fold change comparing nodules vs. N-replete free-living cells.

${ }^{\mathrm{c}}$ Data sets A and B refer to similar experiments performed in our two laboratories.

${ }^{\mathrm{d}}$ Clusters of orthologous genes (COG) classes (Tatusov et al. 2001).

${ }^{\mathrm{e}}$ Core genes are conserved genes in the three strains (ACN, EAN, and CcI3) at a threshold level of $40 \%$ amino acid identity over $80 \%$ of the length of the smaller gene. $+=$ present; $-=$ absent.

${ }^{\mathrm{f}}$ Specific genes are core genes not conserved in Acidothermus cellulolyticus (NC_008578), Streptomyces avermitilis (NC_003155, NC_004719), and S. coelicolor (NC_003888, NC_003903, NC_003904) at a threshold level of 40\% amino acid identity over $80 \%$ of the length of the smaller gene.

g Synteny is the presence of a group of genes in the three strains (ACN, EAN, and CcI3) having $30 \%$ amino acid identity over $80 \%$ of the length of the smaller gene, separated by no more than five intervening sequences.

${ }^{\mathrm{h}}$ Core secretome encompasses 161 conserved secreted proteins in the three strains (ACN, EAN and CcI3) according to Mastronunzio et al (2008). 
genes were significantly up-regulated under both symbiotic and N-fixing FL conditions (Table 5). If GDH and GOGAT are absent in ACN vesicles as previously reported in CpI1 (Schultz and Benson 1990), the very strong repression of GSI and the slight induction of GSII could result in reduction of total ammonium assimilation in vesicle cells of ACN in nodules. As a result, we hypothesize that ammonium would be accumulated in vesicles and, consequently, might diffuse to host plant cells to be assimilated by the host GS (Guan et al. 1996) and to hyphae, in which more highly expressed GDH was observed. Thus, it can be suggested that the host plant tightly limits bacterial ammonium assimilation through inhibition of $g \ln I I$ activation in order to increase ammonium diffusion from the vesicles to host infected cells. To support our hypothesis, it is necessary to determine localization of those enzymes, because nodule RNA used for the microarray analysis was isolated from a mixture of hyphae and vesicles.

Transporters, secretion system, and export proteins. Transporters and molecules secreted by Frankia spp. could provide information about interactions between the symbiont and its host. In the ACN genome, there are 426 genes labeled as involved in transport, export, or efflux, 229 of which are ABC transporters. Surprisingly, only a dozen were differentially expressed, suggesting that nutrients and secondary metabolites exchanged between the two partners may be reduced to the bare essentials, in order to focus bacterial activity on nitrogen fixation. As energy sources for nitrogen fixation, $F$. alni obtains photosynthetic products presumably released through the plant transporter DCTA1, which was identified as a nodulespecific transcript and was shown to transport malate, succinate, fumarate, and oxaloacetate (Jeong et al. 2004). In rhizobia, the $d c t A$ gene product is involved in the uptake of the photosynthetic products $\left(\mathrm{C}_{4}\right.$-dicarboxylates). The corresponding Frankia ACN $d c t A$ gene (FRAAL1390) was not differentially expressed in symbiosis. However, as no $\operatorname{dct} A$ homolog is present in the $\mathrm{CcI} 3$ genome, we can assume that another transporter could take up photosynthetic products. Indeed, several poorly characterized ATP-binding ABC transporters (FRAAL2212, 2213, and 1843) were two- to threefold up-regulated but only in one data set. Thus, the Frankia carbon uptake transporter remains elusive. It is also possible that the reference for the arrays, that is $F$. alni growing on propionate in basal medium with propionate (BAP), uses the same transporter, and thus, no upregulation could be obtained. Transporter genes exhibiting the remarkable expression change were those encoding putative sugar ABC transporter (FRAAL3762 to 3765), which were highly downregulated in nodules (Table 4). Strong repression of sugar transporter clusters in nodules was also observed in B. japonicum, although its function remains unknown (Pessi et al. 2007).

Three genes encoding putative protein drug exporters of the RND (resistance, nodulation, cell division) superfamily (FRAAL3922, 4896, and 1424) were significantly up-regulated, especially the first two ( $\mathrm{FC}=20.6,13.3$, and 2.5 , respectively). Finally, a gene (FRAAL0792) encoding a putative high-affinity branched-chain amino acid ATP-binding ABC transporter was 2.5-fold up-regulated, as were other poorly characterized transporters (FRAAL0725 and 1482).

It is possible that bacterial proteins are secreted to interact with the host, as happens in pathogens such as Mycobacterium tuberculosis (Raghavan et al. 2008) and in rhizobia (Kambara et al. 2009). Protein secretion in F. alni appears to be accomplished by the Tat and the Sec secretory systems (Mastronunzio et al. 2008). Two tat genes were two- to threefold downregulated (tatA, FRAAL2883; tatB, FRAAL6088), while one $s e c$ gene ( $\sec$ G, FRAAL4584) was threefold up-regulated. The potential secretome of the ACN strain comprised 279 proteins, of which 161 orthologous proteins form the core Frankia secretome (Mastronunzio et al. 2008). Ten differentially expressed genes (FRAAL0094, 0725, 1097, 1427, 1432, 1482, 4553, 6657,6658 , and 6801) encode products belonging to the core Frankia secretome; their roles are discussed elsewhere.

Energy production and conversion. Given the high energetic need of the conversion of nitrogen to ammonia, upregulation of genes involved in energy production was expected. Indeed, genes encoding the eight enzymes of the tricarboxylic acid (TCA) cycle were up-regulated, with the highest scores (8.7to 13.6-fold) for succinyl-CoA synthetase (FRAAL1156, 1157), succinate dehydrogenase (FRAAL1187 to 1190), and citrate synthase (FRAAL0111). Also, cluster FRAAL5930 to 5937 encoding ATP synthase subunits was highly induced (up

Table 5. Expression of genes involved in ammonium assimilation and transport

\begin{tabular}{|c|c|c|c|c|c|}
\hline \multirow[b]{2}{*}{ Gene no. ${ }^{a}$} & \multirow[b]{2}{*}{ Gene name $^{\mathrm{a}}$} & \multirow[b]{2}{*}{ Product description $^{\mathrm{a}}$} & \multicolumn{3}{|c|}{ Fold change $^{\mathrm{b}}$} \\
\hline & & & $\mathbf{A}^{\mathbf{c}}$ & $\mathbf{B}^{\mathbf{c}}$ & N- \\
\hline \multicolumn{6}{|c|}{ With differential expression change } \\
\hline FRAAL5161 & $g \ln A$ & Glutamine synthetase I & 0.1 & 0.3 & 0.2 \\
\hline FRAAL5163 & $g \ln I I$ & Glutamine synthetase II & 1.9 & 2.1 & 15.1 \\
\hline FRAAL4964 & glt $D$ & Glutamate synthase small subunit & 4.0 & 3.0 & 3.7 \\
\hline FRAAL4965 & gltB & Glutamate synthase large subunit & 4.5 & 2.7 & 2.9 \\
\hline FRAAL6693 & gdhA & Glutamate dehydrogenase & 5.4 & 3.7 & 1.7 \\
\hline FRAAL0904 & $g \ln B 1$ & Regulatory protein PII for nitrogen assimilation & 7.2 & 2.6 & 11.8 \\
\hline FRAAL0905 & amtB1 & Ammonium transport protein & 6.7 & 2.4 & 9.8 \\
\hline \multicolumn{6}{|c|}{ Without differential expression change } \\
\hline FRAAL0678 & $g \ln A 2$ & Glutamine synthetase & 1.0 & 1.1 & 0.9 \\
\hline FRAAL1887 & glnIII & Glutamine synthetase III & 1.1 & 1.1 & 1.1 \\
\hline FRAAL5165 & $g \ln A 1$ & Glutamine synthetase 2 & 0.6 & 1.3 & 1.2 \\
\hline FRAAL6426 & & Putative glutamine synthetase & 1.2 & 1.4 & 0.9 \\
\hline FRAAL5164 & $\operatorname{gln} E$ & Glutamine-synthetase adenylyltransferase & 1.1 & 1.1 & 1.1 \\
\hline FRAAL1888 & & Putative glutamine amidotransferase & 1.1 & 1.4 & 1.4 \\
\hline FRAAL1889 & $\operatorname{glxC}$ & Glutamate synthase alpha subunit & 1.1 & 1.0 & 1.0 \\
\hline FRAAL1890 & $\operatorname{glx} D$ & Glutamate synthase large subunit & 0.9 & 1.3 & 0.9 \\
\hline FRAAL0903 & $g \ln D$ & PII uridylyl-transferase & 1.3 & 1.1 & 1.0 \\
\hline FRAAL0032 & $g \ln B 2$ & Regulatory protein PII for nitrogen assimilation & 1.4 & 1.3 & 1.4 \\
\hline FRAAL1969 & $a m t B 2$ & Ammonium transport protein & 1.3 & 1.4 & 1.2 \\
\hline
\end{tabular}

${ }^{a}$ Gene number, gene name and product description according to the Genoscope database.

${ }^{\mathrm{b}}$ Fold change comparing nodules vs. N-replete free-living (FL) cells (A and B) and N-fixing FL cells vs. N-replete FL cells (N-). Bold characters indicate significant differential expression change.

${ }^{\mathrm{c}}$ Data sets A and B refer to similar experiments performed in our two laboratories. 
to 8.8-fold) as well as genes encoding cytochrome c or bd oxidase subunits (FRAAL0598, 0599, 4147, 5122, 5123), in particular $c t a D$ and $c y d A$ (up to 14.6-fold). Interestingly, Rhizobium phaseoli cytochrome c-deficient mutant induced empty nodules on Phaseolus vulgaris, supporting a role for c-type cytochrome in nodule infection (Soberon et al. 1993). In addition, cytochrome bd may play an important role in microaerobic nitrogen fixation since, in the enteric bacterium Klebsiella pneumoniae, it is expressed under all conditions that permit diazotrophy (Juty et al. 1997), and in Azotobacter vinelandii, disruption of the gene resulted in the loss of nitrogen-fixing ability (Kelly et al. 1990). The ppa gene (FRAAL6584) encoding inorganic pyrophosphatase was up-regulated. All these results fit with the high energy requirement of the nitrogen fixation process and explain that genes belonging to $\mathrm{COG}$ class $\mathrm{C}$ (energy production and conversion) are overrepresented and mostly upregulated in nodules (Fig. 2).

DNA metabolism, transcription, translation, and chaperones. Expression changes in fundamental cellular processes as well as in specific transcriptional regulators could give insight into Frankia physiology inside nodules. We found only a few genes involved in DNA metabolism (replication, recombination, and repair) showing differential expression change, among them a highly upregulated $(\mathrm{FC}=18.2)$ gene encoding a putative integration host factor-like protein (FRAAL5232) and two upregulated genes involved in repair of DNA damaged by oxidation (mutM, FRAAL5802 and putative mutT, FRAAL2463). In contrast, another putative mutT gene (FRAAL4301) was down-regulated. The role of integration host factors in stimulating transcription from the $\sigma^{54}$-dependant nifH promoter in a variety of bacteria has been reported (Hervas et al. 2009; Santero et al. 1992; Wassem et al. 2000). More genes involved in transcription and its related functions were induced, beta and sigma subunits of RNA polymerase, transcription terminator Rho, ribonuclease III, antitermination protein NusG, and DEAD-box RNA helicase. Seven genes encoding transcriptional regulators showed increased expression in symbiosis, and all were conserved or syntenic in the three Frankia strains (Table 6). They contained two LuxR- and a MarR-family members. LuxR-type helix-turn-helix (HTH) regulators control a wide variety of activities in various biological processes, among them is the Rhizobiaceae FixJ regulator that induces expression of nitrogen-fixation genes under microaerobic conditions (Birck et al. 2002). Regulators with the MarR-type HTH domain control stress-related biological functions, such as resistance to oxidative stress and regulation of the virulence factor synthesis in pathogens of humans and plants, and respond to aromatic compounds (Alekshun and Levy 1999; Egland and Harwood 1999). In addition, a putative fur (ferric uptake regulator) gene (FRAAL5117) was up-regulated. The regulation is as expected, since iron is a key element for the activity of nitrogenase and many other related iron-sulfur enzymes (uptake hydrogenase, ferredoxins, IspG, etc.). Six genes encoding transcriptional regulators were down-regulated. The most downregulated one (FRAAL6548) coded for a putative transcriptional regulator of the WhiB family, conserved in EAN and CcI3 (Tables 4 and 6). WhiB is a transcription factor of actinobacteria required for differentiation and sporulation. The process of aerial mycelia formation in Streptomyces aureofaciens, which occurs in response to nutrient limitation, is controlled by a number of whi genes (Kormanec and Homerova 1993). The mycobacterium whmD gene, which encodes a homolog of $\mathrm{WhiB}$, is required for proper septation and division (Gomez and Bishai 2000). The major cellular rearrangements members of genus Frankia spp. undergo as they switch from a FL lifestyle to a symbiotic intercellular one presumably entails such regulators; thus, we expected to see important up- or downregulation in differentiation-related regulators.

COG class $\mathbf{J}$ (translation, ribosomal structure, and biogenesis) was the second class overrepresented by upregulated genes (Fig. 2), including two clusters encoding ribosomal proteins (FRAAL1064 to 1115 and 5779 to 5812), numerous genes involved in translation machinery and four genes involved in the synthesis of aminoacyl tRNAs (gatABC, FRAAL5853 to 5856 and $p t h$, FRAAL6266), whereas cysS2 (FRAAL2858) was repressed. A groL gene (FRAAL6486) encoding the chaperone Hsp60 was strongly induced in nodule $(\mathrm{FC}=40.3)$, suggesting a predominant role of this chaperone under these conditions (Table 3). In contrast, clusters of chaperone-encoding genes dnaK-grpE-dnaJ-hsrP-clpB (FRAAL6639 to 6643) and $c l p B$ dnaJ-grpE-dnaK (FRAAL2601 to 2605) were not differentially expressed and $h s p l 8$ (FRAAL4031) was highly down-

Table 6. Transcriptional regulator genes differentially expressed in nodules in the two data sets

\begin{tabular}{|c|c|c|c|c|c|c|}
\hline \multirow[b]{2}{*}{ Gene no. ${ }^{a}$} & \multirow[b]{2}{*}{ Product description $^{\mathrm{a}}$} & \multicolumn{2}{|c|}{ Fold change $^{b}$} & \multirow[b]{2}{*}{ Core $^{c}$} & \multirow[b]{2}{*}{ Spe. ${ }^{d}$} & \multirow[b]{2}{*}{ Syn. ${ }^{\mathrm{e}}$} \\
\hline & & $\mathbf{A}$ & B & & & \\
\hline \multicolumn{7}{|c|}{ Upregulated genes } \\
\hline FRAAL4858 & Putative LuxR-family transcriptional regulator & 13.7 & 8.3 & + & - & - \\
\hline FRAAL2921 & Hypothetical protein (repressor-like DNA-binding domain) & 10.7 & 12.0 & - & - & + \\
\hline FRAAL0711 & Putative MarR-family transcriptional regulator & 8.9 & 3.0 & + & - & + \\
\hline FRAAL1544 & Putative LuxR-family transcriptional regulator & 8.7 & 5.5 & + & + & + \\
\hline FRAAL1491 & Putative helix-turn-helix (HTH)-type transcriptional regulator & 5.1 & 4.6 & + & + & + \\
\hline FRAAL5117 & Putative Fur-family transcriptional regulator & 3.3 & 3.1 & + & - & + \\
\hline FRAAL5617 & Putative AbaA-like regulator protein & 3.0 & 3.9 & + & - & + \\
\hline \multicolumn{7}{|c|}{ Downregulated genes } \\
\hline FRAAL1768 & Putative $\mathrm{CrP} / \mathrm{Fnn}$-family transcriptional regulator & 0.4 & 0.3 & - & - & - \\
\hline FRAAL5839 & Putative $\mathrm{CrP} / \mathrm{Fnn}$-family transcriptional regulator & 0.3 & 0.3 & + & + & + \\
\hline FRAAL6525 & Putative CarD-like transcriptional regulator & 0.2 & 0.3 & + & - & + \\
\hline FRAAL0198 & Putative transcriptional regulator & 0.2 & 0.1 & - & - & - \\
\hline FRAAL0140 & Putative HTH-type transcriptional regulator & 0.1 & 0.1 & - & - & - \\
\hline FRAAL6548 & Putative WhiB-family transcriptional regulator & 0.1 & 0.1 & + & - & + \\
\hline
\end{tabular}


regulated (Table 4). The high number of induced genes in COG class $\mathrm{J}$ could be necessary for the biosynthesis of nitrogen-fixation machinery such as vesicles.

Stress defense and detoxification. Maybe due to the adaptation to a protected biotope, symbiosis does not seem to be a stressful condition, except for oxidative stress, since several heat-shock proteins genes involved in adaptation to stress (FRAAL0094, 1053, and 4243) were highly down-regulated, whereas genes involved in detoxification of reactive oxygen species such as the $b c p$ gene (FRAAL5045) encoding a peroxiredoxin that detoxifies $\mathrm{H}_{2} \mathrm{O}_{2}$ and alkyl hydroperoxides (Barr and Gedamu 2001) $(\mathrm{FC}=4.2)$ and $\operatorname{sodF}$ (FRAAL4337) encoding superoxide dismutase $1(\mathrm{FC}=2.9)$ were up-regulated in nodules. Interestingly, peroxiredoxin and SodF were reported to be induced upon addition of root exudates (Hammad et al. 2001). In contrast, the katA gene (FRAAL3167) encoding catalase A, which catalyzes the conversion of $\mathrm{H}_{2} \mathrm{O}_{2}$ to molecular oxygen was down-regulated in data set B. However, we noticed that katA as well as sodF showed very high microarray signals (among the 100 highest) under symbiotic conditions as well as under FL conditions. Barnett and associates (2004) reported that the probe sets with highest average signal values (within the top 100) correlated well with computer-based predictions of highly expressed genes in Sinorhizobium meliloti. Therefore, the katA gene would be highly expressed and play a role in nodule even though it is down-regulated. In addition, previous reported studies further sustain this idea, since they showed that ACN catalase has a very high constitutive activity under nitrogen-replete FL conditions (Santos et al. 2007). Incidentally, we observed that the second kat gene, katB (FRAAL3889), which was not significantly down-regulated, showed low microarray signals in FL condition and in symbiosis, i.e., $>30$-fold smaller than the katA gene, suggesting a minor contribution of KatB to catalase activity, at least under these conditions. We also noticed that the gene neighboring sod, the $b f r$ A gene (FRAAL4338) encoding an iron-storage protein bacterioferritin, was up-regulated $(\mathrm{FC}=3.5)$ and, like sodF and katA, among the 100 highest microarray signals under FL and symbiotic conditions, suggesting a need for coordinated expression.

Lipopolysaccharides and cell-wall peptidoglycans. Surface polysaccharides such as LPS play important roles in promoting the rhizobial infection of root nodules. In particular, Sinorhizobium meliloti mutants of the lpsB gene, which encodes a protein of the glycosyl transferase 1 family participating in the biosynthesis of the LPS core, failed to effectively colonize Medicago nodules (Campbell et al. 2002). Moreover the lpsB gene was induced in $S$. meliloti bacteroids (Becker et al. 2004). In the ACN genome, several dozens of putative genes related to biosynthesis of surface polysaccharide are found. Interestingly, among them, a gene encoding a glycosyl transferase related to the GT1 family (FRAAL5287) was strongly up-regulated. However, it was a stark contrast to the rhizobial transcriptome, in which 17 genes related to polysaccharide synthesis showed significant expression changes in nodule (Becker et al. 2004).

Most genes coding for peptidoglycan synthesis were not differentially expressed, except for four genes, murl (FRAAL1505) encoding glutamate racemase $(\mathrm{FC}=5.9)$, rfe (FRAAL5941) encoding undecaprenyl $N$-acetylglucosaminyl transferase $(\mathrm{FC}=3)$, and two neighboring genes (FRAAL6657 and 6658) encoding $N$-acetylmuramoyl-L-alanine amidase (autolysin) $(\mathrm{FC}=10.5$; Table 3$)$ and a hypothetical protein with a lysozyme-like domain $(\mathrm{FC}=3.9)$ coherent with either cell-wall remodeling in relation to vesicle synthesis or possibly with senescing cells. These two last genes belong to the core Frankia secretome (Mastronunzio et al. 2008). It is interesting that two lytic transglycosylases were highly induced, which raises the question of their contribution to effective invasion of
F. alni to plant cells as reported in an animal pathogen (Cabanes et al. 2004).

Nod factors and signaling processes. The Rhizobium nod genes encode the enzymes that synthesize lipo-chito-oligosaccharides, called Nod factors, which are the signal molecules initiating symbiosis. In genomes studied so far, the genes homologous to $\operatorname{nod} B, \operatorname{nod} C$, $\operatorname{nod} D$, and $\operatorname{nod} Q$ are present but, as in many organisms, at low levels of sequence identity, and they are not clustered or organized in operons (Normand et al. 2007a). Our results showed that the expression of neither of these genes was changed between FL conditions and symbiosis, so the question of their putative role in nodulation remains open.

On the other hand, two genes involved in signaling processes were up-regulated, a gene (FRAAL1155) encoding a putative serine and threonine kinase $(\mathrm{FC}=12)$ and $r s h A$ gene (FRAAL5991) encoding an anti-sigma factor $(\mathrm{FC}=4.8)$. In contrast, a gene (FRAAL5664) encoding a putative tyrosinespecific protein phosphatase was down-regulated $(\mathrm{FC}=0.1)$. This gene labeled as specific is highly conserved in the three Frankia strains. Tyrosine-specific protein phosphatases are key regulatory components in signal transduction pathways and are important in the control of cell cycle, cell growth, proliferation, differentiation, and transformation (Denu and Dixon 1998).

Secondary metabolism. In the genome, most genes categorized in COG class Q (secondary metabolites biosynthesis, transport, and catabolism), such as those encoding nonribosomal peptide synthetases and polyketide synthases, did not show differential expression change. Those differentially expressed were mostly down-regulated, which again suggests that exchanges of metabolites with host plant are reduced to the bare essentials.

Hypothetical proteins. A total of $49 \%$ of the genes in the ACN genome encode hypothetical proteins. Interestingly, when located in a gene cluster with known function, these genes often displayed similar regulation with surrounding known genes, suggesting a similar role for them. For instance, FRAAL6806 and 6816 in the nif cluster may have a role in nitrogen fixation (Fig.3A). Hypothetical genes showing highly differential expression changes are worthy of attention, in particular, those belonging to the core gene subset such as FRAAL3254 $(\mathrm{FC}=38.8)$ (Table 3$)$ and FRAAL1014 $(\mathrm{FC}=$ 0.043) (Table 4).

\section{Comparison of Frankia transcriptomes between Alnus nodules and N-fixing FL cells.}

In the absence of an organic source of nitrogen, FL Frankia cells can fix nitrogen, whereas most rhizobia cannot. However, vesicle formation of $F$. alni in N-starved FL conditions differs from that in nodules. Briefly, in nodules, vesicles are more numerous and have a markedly different shape, being much larger, less spherical, and more septated than in N-fixing FL conditions (Benson and Silvester 1993). Nevertheless, it was decided to compare transcriptomes between N-fixing FL cells and symbiotic cells, in order to try to clarify which genes are associated with nitrogen fixation and which are associated with nodule symbiotic interactions. Indeed, 96 (33\%) of the 292 genes differentially expressed in symbiosis vs. N-replete FL cells showed significant expression change in N-fixing FL vs. N-replete FL cells (Supplementary Table 5). Remarkably, all of these genes displayed similar up- or downregulation in the two conditions, however, often not in the same proportion. In particular, nif genes (FRAAL6811 to 6814) showed much lower FC (about 13fold) in FL N-fixing cells, and furthermore, all other genes of the nif cluster did not display significant differential expression. These results reveal much lower N-fixation under N-fixing FL conditions than in symbiosis, which correlates with morphologi- 
cal differences of vesicles described above. It is quite likely that in N-fixing FL conditions, gene expression of vesicles was hidden behind that of hyphae, which are much more predominant. One consequence of this observation is that we cannot conclude that all the genes showing differential expression only in nodules are related to nodulation. On the other hand, most of the 96 genes that were differentially expressed under both symbiotic and N-fixing FL conditions could be associated with nitrogen fixation. In addition to nif genes, we found upregulated genes likely involved in nitrogen fixation-related functions or associated to vesicle formation, such as $f d x I$ (ferredoxin), sufCE (Fe-S clusters), $i s p G$ (isopentenyl diphosphate synthesis), as well as many genes classified into $\mathrm{COG}$ class $\mathrm{C}$, reflecting the high energy requirements for nitrogen fixation (ATP synthase, TCA cycle, cytochrome c), and genes classified into COG classes $\mathrm{K}$ (RNA polymerases, LuxR, and AbaA-like transcriptional regulators) and J (ribosomal proteins, glutamyl-tRNA, chaperone GroL), which, as suggested for symbiosis results, could be related to vesicle biosynthesis. Thus, these comparative results allowed us to clearly assign nitrogen fixation-related function to some genes and highlighted the difficulties and limits of such transcriptome analyses with heterogeneous multicellular organism.

\section{Comparison of Frankia transcriptomics data from two Alnus and two Myricaceae species.}

Unlike rhizobia, which nodulate only Fabaceae plants, Frankia spp. establish symbiosis with a wide variety of plants belonging to different families, and $F$. alni, in particular, can nodulate Alnus and Myrica species. Therefore, it is of great interest to know how host plants belonging to different families affect Frankia transcriptome in nodules. We harvested ACN14a-infected nodules formed on Alnus nepalensis, Myrica gale, and Morella rubra and used them for microarray analyses. Supplementary Figure 1 shows scatter plots of the fold expression changes (nodule vs. N-replete FL cells) for all pairwise comparisons of the trees. Most of the data plotted close to a diagonal line, and correlation coefficients between two trees were high $(>0.9)$. There were 224 genes showing significant expression change in all the four trees (Table 1), and all of them, except for FRAAL0302, displayed similar up- or downregulation (Supplementary Table 6). FRAAL0302, as mentioned above, displayed opposite regulation in the two data sets of $A$. glutinosa. Those results collectively indicate that nodule transcriptomes of $F$. alni are similar among phylogenetically distant plant families.

When genes without significant expression change were taken into account, we found several genes showing different expression patterns between the two plant families (Supplementary Table 7). Most of them showed similar up- or downregulation, but fold change levels were different. Notably, genes encoding subunits of $\mathrm{NADH}$ dehydrogenase showed more obvious downregulation in Myricaceae nodules. This regulation may reflect differences in accessibility to oxygen,

Table 7. Expression profiles of orthologous genes in Frankia alni ACN14a and Sinorhizobium meliloti

\begin{tabular}{llrccc}
\hline & & \multicolumn{3}{c}{ Sinorhizobium meliloti } \\
\cline { 3 - 6 } Strain & Expression & $\mathbf{U p}^{\mathbf{a}}$ & Down $^{\mathbf{b}}$ & N.S. $^{\mathbf{c}}$ & Total \\
\hline \multirow{2}{*}{ ACN } & Up $^{\mathrm{a}}$ & 11 & 33 & 28 & 72 \\
& Down $^{\mathrm{b}}$ & 3 & 5 & 22 & 30 \\
& N.S. $^{\mathrm{c}}$ & 58 & 185 & - & 243 \\
& Total & 72 & 223 & 50 & 345 \\
\hline
\end{tabular}

a Number of genes upregulated in nodules.

${ }^{\mathrm{b}}$ Number of genes downregulated in nodules.

${ }^{\mathrm{c}}$ Number of genes that did not show significant expression change. probably caused by nodule architecture (Huss-Danell 1997). In addition, a $s h c$ gene (shc2, FRAAL2491) that did not show significant expression change in Alnus nodules was prominently up-regulated in Myricaceae nodules, suggesting a possible relationship with difference in vesicle structure between the two plant families (Huss-Danell 1997). Interestingly, the shc2 gene is followed by a gene encoding a predicted redox sensor that could be implicated in regulating oxygen response in nodules (Alloisio et al. 2005).

\section{Comparison of Frankia transcriptome with rhizobia.}

We compared the nodule transcriptome of $F$. alni species with that of rhizobia. Although several microarray analyses were reported in rhizobia, we selected transcriptomic data from Capela and associates (2006) on Sinorhizobium meliloti, because their experimental conditions are similar to those used in the present study; they used FL cells at mid-log phase cultured in a defined minimal medium containing an organic source of nitrogen and symbiotic cells from young (8 days postinoculation) nitrogen-fixing nodules.

Frankia ACN and S. meliloti shared 1,179 orthologs (Supplementary Table 8). About 30\% (345 genes) of them showed significant expression change in either ACN or $S$. meliloti between nodules and FL conditions (Table 7). In ACN, more genes were up-regulated in nodules (upregulated/downregulated genes [72:30] $=2.4: 1$, while more genes were down-regulated in $S$. meliloti nodule (upregulated/downregulated genes [72:223] = $1: 3.1$ ), indicating that transcriptomes in nodules were largely different between the two symbiotic bacteria. As a consequence, only 16 genes (4.6\% of 345) showed consistent regulation (upor downregulated in both bacteria). Dominant genes upregulated in both bacteria were nif as expected. Most of the upregulated genes in ACN were down-regulated or did not show significant expression change in S. meliloti (61 of 72 genes, 85\%) (Table 7). Many of those genes are classified into COG classes $\mathrm{C}$ and $\mathrm{J}$. They are related to 'energy production and conversion' (TCA cycle, respiration chain, ATP synthase) and 'translation, ribosomal structure and biogenesis' (ribosomal proteins, translation factors). Downregulation of such genes in nodules was also found in other rhizobial experiments (Barnett et al. 2004; Becker et al. 2004; Pessi et al. 2007). These results suggest that in nodules, F. alni, is metabolically more active than rhizobia, which is commensurate with the fact that $F$. alni is more autonomous than rhizobia; for instance, it must synthesize vesicles to deal with the lack of protection provided by the host.

\section{Validation of microarray experiments.}

To confirm the results obtained from microarray analysis, we performed quantitative reverse transcription (qRT)-PCR (Table 8). Fifteen genes showing various levels of expression change, belonging to different pathways, and spreading over the various positions of the genome were chosen. Comparison was made with data obtained from the same samples of RNA using the two distinct techniques. We found excellent agreement between the microarray and qRT-PCR data in both data sets, indicating the reliability of our microarray data, except only for a remarkable discordance in hupL2 (FRAAL1829) in data set B, in which qRT-PCR detected a 207 -fold upregulation, whereas the microarray detected only a threefold increase. This result was reproduced using a different pair of primers and RNA from other biological replicates (data not shown). This is probably due to the higher sensitivity of qRT-PCR for differential expression.

\section{Conclusion.}

In the present study, we conducted the transcriptional profiling of F. alni under N-replete FL and symbiotic conditions. 
The data obtained showed that $F$. alni do not contain a symbiotic island consisting of numerous nodule-induced genes, as was found in some rhizobia. However they indicated that nodule-induced genes are distributed mostly over several regions with high synteny. In addition to the expected high upregulation of the genes related with nitrogen fixation (nif, hup2, suf, $i s p G$, shcl, etc.), our genome-wide transcriptional analysis revealed some unexpected features concerning genes such as those involved in ammonium assimilation $(g \ln I I)$ or $\mathrm{C}_{4}$-dicarboxylate uptake $(\operatorname{dct} A)$. A large number of induced genes involved, in particular, in transcriptional regulation, signaling processes, protein drug export, protein secretion, lipopolysaccharide, and peptidoglycan biosynthesis that may play a role in nodulation were also identified. Comparison of nodule and $\mathrm{N}$ fixing FL $F$. alni transcriptomes allowed us to assign differential expression of some genes to nitrogen fixation and related functions. This Frankia nodule transcriptome of was highly similar among phylogenetically distant plant families. In contrast, the comparison of Frankia transcriptome with rhizobia indicates that the two bacterial transcriptomes were largely different in nodules and suggests that $F$. alni is metabolically more active, which could be related to vesicle biosynthesis. Globally, this transcriptomic pattern suggests that $F$. alni is a nitrogen-fixing machine in symbiosis.

Our Frankia microarray provides a useful tool to investigate gene expression pattern in various biological conditions, such as the early stages of infection, which are of particular interest in the absence of known signal molecules initiating symbiosis. However microarray analysis does not take into account the absolute transcript levels, so genes showing constitutive high expression, which must obviously play a role, are underestimated. Therefore other approaches such as proteomic or large scale cDNA sequencing could complete this first global gene expression dissection of $F$. alni in symbiosis.

\section{MATERIALS AND METHODS}

\section{Bacterial strain and growth conditions.}

In order to obtain rapid exponential growth, $F$. alni ACN14a (Normand and Lalonde 1982) was grown according to Schwencke $(1991)$ at $28^{\circ} \mathrm{C}$ with stirring at $200 \mathrm{rpm}$ in defined (BAP) containing $5 \mathrm{mM}$ ammonium chloride (N-replete condition) or not (N-fixing condition) (Murry et al. 1984) with some minor modifications. Fe-citrate $(10 \mathrm{mg} / \mathrm{liter})$ was used instead of FeNa-EDTA, $\mathrm{CoSO}_{4} \cdot 7 \mathrm{H}_{2} \mathrm{O}(0.001 \mathrm{~g} /$ liter $)$ was added in the micronutrient stock solution, and biotin was replaced by the vitamin mixture described by Tjepkema and associates (1981). Before starting cultures, $F$. alni cells were centrifuged and were washed twice with corresponding BAP media in order to discard ammonium chloride in $\mathrm{N}$-fixing cultures. After 5 days of culture, stirring was stopped. Supernatants were carefully discarded, and cells were immediately stored at $-80^{\circ} \mathrm{C}$ in the $\mathrm{A}$ experiments or treated with RNAprotect bacteria reagent (Qiagen, Courtaboeuf, France) for stabilization of RNA before freezing at $-80^{\circ} \mathrm{C}$ in the $\mathrm{B}$ experiments. Three biological replicates were performed.

\section{Plants, growth conditions, and nodule isolation.}

Seeds of A. glutinosa, A. nepalensis, Myrica gale, and Morella rubra were planted and grown for five to ten weeks in a soil/vermiculite substrate $(1: 1, \mathrm{vol} / \mathrm{vol})$ in a glasshouse under fluorescent lighting with a 16-h light and 8-h nycthemeral regime at temperature 21 to $25^{\circ} \mathrm{C}$. Seedlings were transferred to Broughton and Dilworth's solution (1971) in plastic pots. They were grown for four to nine weeks with $0.5 \mathrm{~g}$ of $\mathrm{KNO}_{3}$ per liter and, then, for one week without $\mathrm{KNO}_{3}$. F . alni $\mathrm{ACN1} 14$ cells derived from $75 \mathrm{ml}$ of log-phase culture were inoculated to a pot. Root nodules ( $\leq 3$ lobes) were harvested into liquid nitrogen at 3 to 4 weeks postinoculation and were stored at $-80^{\circ} \mathrm{C}$. Nodules from about 24 plants per replicate were pooled for RNA extraction, and three biological replicates were performed.

\section{RNA purification.}

RNA from FL ACN and A. glutinosa nodules in A experiments and from nodules of $A$. nepalensis, $M$. gale, and M. rubra was purified following a procedure described by Kucho and associates (2009). In B experiments, RNA was purified from bacterial cells and nodules using RNeasy plant mini kit (Qiagen) and on-column DNA digestion with the RNase-free DNase set (Qiagen). In order to avoid any remaining DNA contaminations, a second DNase treatment was performed with RQ1 RNase-free DNase (Promega, Charbonnières-lesBains, France), followed by RNA cleanup using RNeasy mini kit. Purity, concentration, and quality of RNA samples were checked using a NanoDrop 1000 spectrophotometer (Thermo Fischer Scientific, Courtaboeuf, France) or Ultrospec 3300 pro photospectrometer (Amersham Biosciences, Buckinghamshire, U.K.) and agarose gel electrophoresis.

Table 8. Validation of microarray results by quantitative reverse transcription-polymerase chain reaction (qPCR)

\begin{tabular}{|c|c|c|c|c|c|c|}
\hline \multirow[b]{3}{*}{ Gene no. ${ }^{a}$} & \multirow[b]{3}{*}{ Gene Name } & \multirow[b]{3}{*}{ Product description } & \multicolumn{4}{|c|}{ Fold change $^{b}$} \\
\hline & & & \multicolumn{2}{|c|}{$\mathbf{A}$} & \multicolumn{2}{|c|}{ B } \\
\hline & & & Array & $\mathbf{q P C R}^{\mathrm{c}}$ & Array & $\mathbf{q P C R}^{\mathrm{c}}$ \\
\hline FRAAL0111 & gltA & Citrate synthase & 10.6 & 9.1 & 9.6 & 13.9 \\
\hline FRAAL0905 & amtB1 & Ammonium transport protein & 6.7 & 6.4 & 4.7 & 17.3 \\
\hline FRAAL1239 & & Putative polysaccharide $\mathrm{ABC}$ transport subunit & 1.5 & 0.8 & 3.2 & 2.8 \\
\hline FRAAL1248 & & Putative glycosyl transferase & 1.2 & 1.3 & 3.9 & 5.1 \\
\hline FRAAL1829 & hupL2 & [NiFe] uptake hydrogenase large subunit & 22.2 & 19.0 & 2.8 & 206.8 \\
\hline FRAAL2088 & $d x s$ & 1-Deoxy-D-xylulose-5-phosphate synthase & 7.5 & 14.1 & 5.2 & 6.7 \\
\hline FRAAL3103 & paaA & Putative phenylacetic acid degradation protein & 0.2 & 0.3 & 0.3 & 0.3 \\
\hline FRAAL3167 & katA & Catalase & 0.5 & 1.1 & 0.3 & 0.5 \\
\hline FRAAL3763 & & Putative sugar $\mathrm{ABC}$ transporter & 0.19 & 0.08 & 0.02 & 0.04 \\
\hline FRAAL4147 & $c t a D$ & Cytochrome c oxidase polypeptide I & 12.7 & 18.3 & 10.5 & 8.5 \\
\hline FRAAL4901 & pheA & Prephenate dehydratase & 1.8 & 0.3 & 1.6 & 3.2 \\
\hline FRAAL5116 & $r r$ & Rubrerythrin & 1.9 & 0.8 & 0.7 & 3.1 \\
\hline FRAAL5161 & $g \ln A$ & Glutamine synthetase I & 0.05 & 0.04 & 0.2 & 0.5 \\
\hline FRAAL5772 & $i s p G$ & 1-Hydroxy-2-methyl-2-(E)-butenyl 4-diphosphate synthase & 4.2 & 2.5 & 13.6 & 4.3 \\
\hline FRAAL6813 & nifH & Nitrogenase reductase & 396.4 & $1,023.3$ & 111.1 & $7,003.7$ \\
\hline
\end{tabular}

${ }^{a}$ Gene number, gene name, and product description according to the Genoscope database.

${ }^{\mathrm{b}}$ Ratio of nodules to N-replete free-living cells. Comparisons were made using a biological replicate of each condition.

${ }^{\mathrm{c}} \mathrm{qPCR}=$ quantitative polymerase-chain reaction. Expression was normalized using the housekeeping infC gene (FRAAL5216). 
Design of the $F$. alni whole-genome microarray.

Based on the sequence and annotation data for $F$. alni ACN14a genome publicly available (Normand et al. 2007b), a whole-genome high-density microarray was designed and manufactured by Roche NimbleGen, Inc. (Madison, WI, U.S.A.). Due to high GC content $(72.8 \%)$ of the $F$. alni genome, a 60-mer oligo length was chosen for probe design. NimbleGen design rules and analysis algorithms found probes for 6,607 genes out of 6,786. In the microarray used for experiments B, 18 probes per gene were obtained for 6,340 genes and $<18$ probes per gene were obtained for 267 genes. In the microarrays used for experiments $\mathrm{A}$ and those for $A$. nepalensis, $M$. gale, and $M$. rubra, four-plex format was applied, in which 11 probes per gene were retained for 6,440 genes and $<11$ probes per gene were retained for 167 genes. Probes were duplicated on the array.

\section{Microarray experiment and data analysis.}

Quality analysis of RNA, synthesis, and labeling of doublestranded cDNA, hybridization, scanning, and data extraction were performed by the NimbleGen expression service laboratory (Tokyo and Reykjavik, Iceland) according to its standard protocol, except that three times more nodule cDNA than FL bacteria was used for hybridization in order to equalize amounts of bacterial cDNA in each condition, since the proportion of bacterial/plant RNA in nodules was roughly 1:3. Normalization of the signal intensity was performed using a quantile normalization method (Bolstad et al. 2003). Normalized gene expression values were generated using the robust multichip average algorithm (Irizarry et al. 2003). We used GeneSpring gene expression analysis software 7.3 (Agilent Technologies, Massy, France) for statistical comparisons and filtering of the data. Genes showing significant differential expression between two biological conditions were selected based on the following three criteria: i) a $P$ value $\leq 0.05$, using the Welch $t$ test with the multiple testing correction of Benjamini and Hochberg (1995), ii) a fold change $\geq 1.8$ in all nine pairwise comparisons yielded by the three biological replicates of each conditions $(3 \times 3)$, and iii) an average fold change $\geq 2$. It is noteworthy that with such stringent criteria, putative differentially expressed genes with moderate fold change or standard deviation were lost.

\section{qRT-PCR analysis.}

qRT-PCR was performed using two procedures. In experiments A, reverse transcription was performed at $50^{\circ} \mathrm{C}$ for 15 min with a PrimeScript RT reagent kit (Perfect Real Time) (Takara Bio, Ohtsu, Japan) and real-time PCR was performed using $20 \mu \mathrm{l}$ of reaction mixture with SYBR Premix Ex Taq II (Perfect Real Time) (Takara Bio), using a 7300 real-time PCR system (Applied Biosystems, Foster City, CA, U.S.A.). The PCR conditions were as follows: $95^{\circ} \mathrm{C}$ for $10 \mathrm{~s} ; 40$ cycles of $95^{\circ} \mathrm{C}$ for $5 \mathrm{~s}, 60^{\circ} \mathrm{C}$ for $31 \mathrm{~s}$. In experiments $\mathrm{B}$, we performed reverse transcription at $55^{\circ} \mathrm{C}$ for $30 \mathrm{~min}$ with Transcriptor reverse transcriptase and random hexamers as primers (Roche, Mannheim, Germany) and real-time PCR using $20 \mu \mathrm{l}$ of reaction mixture with LightCycler 480 SYBR Green I Master (Roche), amplified on a LightCycler 480 (Roche). The PCR conditions were as follows: $95^{\circ} \mathrm{C}$ for 5 min; 45 cycles of $95^{\circ} \mathrm{C}$ for $20 \mathrm{~s}, 60^{\circ} \mathrm{C}$ for $20 \mathrm{~s}$, and $72^{\circ} \mathrm{C}$ for 15 s. cDNA derived from 50 or 100 ng RNA was used for a PCR reaction in experiments $B$ and A, respectively. Genes and primers used are listed in Supplementary Table 9. Expression values were normalized to the expression of infC (FRAAL5216), encoding protein chain initiation factor 3, whose expression showed little variability between nodule and FL conditions on arrays.
Comparison of Frankia transcriptome with rhizobium.

We obtained a list of Sinorhizobium meliloti genes showing the bidirectional best hit with each gene of Frankia ACN14a from the Kyoto Encyclopedia of Genes and Genomes sequence similarity database. We determined a $S$. meliloti gene to be an ortholog if it showed amino-acid sequence similarity with an ACN14a counterpart over $70 \%$ or more of its length. Microarray data of $S$. meliloti were obtained from supplementary data published by Capela and associates (2006). We determined an expression change was statistically significant if $\log _{2} \mathrm{FC}(\mathrm{M})$ was $>1$ or $<-1$ and the $t$-test $P$ value was $<0.01$.

\section{ACKNOWLEDGMENTS}

Thanks are expressed to A. Wierinckx and J. Lachuer from ProfileXpert (Lyon, France) for GeneSpring analysis of NimbleGen array data, to D. Abrouk and the PRABI (IFR41) for help in data processing, to D. Desbouchages (IFR41) for use of the greenhouse, and to F. Tavares (University of Porto, Portugal) for comments on the manuscript. We acknowledge research grants from the French ANR Blanc 7 "Newnod" and from the Centre National de la Recherche Scientifique "EC2CO".

\section{LITERATURE CITED}

Alekshun, M. N., and Levy, S. B. 1999. The mar regulon: Multiple resistance to antibiotics and other toxic chemicals. Trends Microbiol. 7:410413.

Alloisio, N., Maréchal, J., Heuvel, B., Normand, P., and Berry, A. 2005. Characterization of a gene locus containing squalene-hopene cyclase (shc) in Frankia alni ACN14a, and an shc homolog in Acidothermus cellulolyticus. Symbiosis 39:83-90.

Alloisio, N., Félix, S., Maréchal, J., Pujic, P., Rouy, Z., Vallenet, D., Medigue, C., and Normand, P. 2007. Frankia alni proteome under nitrogen-fixing and nitrogen-replete conditions. Physiol. Plant. 13:440-453.

Barnett, M. J., Toman, C. J., Fisher, R. F., and Long, S. R. 2004. A dualgenome symbiosis chip for coordinate study of signal exchange and development in a prokaryote-host interaction. Proc. Natl. Acad. Sci. U.S.A. 101:16636-16641.

Barr, S. D., and Gedamu, L. 2001. Cloning and characterization of three differentially expressed peroxidoxin genes from Leishmania chagasi. Evidence for an enzymatic detoxification of hydroxyl radicals. J. Biol. Chem. 276:34279-34287.

Becker, A., Bergès, H., Krol, E., Bruand, C., Rüberg, S., Capela, D., Lauber, E., Meilhoc, E., Ampe, F., de Bruijn, F. J., Fourment, J., Francez-Charlot, A., Kahn, D., Küster, H., Liebe, C., Pühler, A., Weidner, S., and Batut, J. 2004. Global changes in gene expression in Sinorhizobium meliloti 1021 under microoxic and symbiotic conditions. Mol. Plant-Microbe Interact. 17:292-303.

Benjamini, Y., and Hochberg, Y. 1995. Controlling the false discovery rate: A practical and powerful approach to multiple testing. J. Roy. Statist. Soc. Ser. B 57:289-300.

Benson, D. R., and Silvester, W. B. 1993. Biology of Frankia strains, actinomycete symbionts of actinorhizal plants. Microbiol. Rev. 57:293319.

Berry, A., Kahn, R., and Booth, M. 1989. Identification of indole compounds secreted by Frankia HFPArI3 in defined culture medium. Plant Soil 118:205-209.

Berry, A., Harriott, O., Moreau, R., Osman, S., Benson, D., and Jones, A. 1993. Hopanoid lipids compose the Frankia vesicle envelope, presumptive barrier of oxygen diffusion to nitrogenase. Proc. Natl. Acad. Sci. U.S.A. 90:6091-6094.

Birck, C., Malfois, M., Svergun, D., and Samama, J. 2002. Insights into signal transduction revealed by the low resolution structure of the FixJ response regulator. J. Mol. Biol. 321:447-457.

Bloch, C. A., and Rode, C. K. 1996. Pathogenicity island evaluation in Escherichia coli $\mathrm{K} 1$ by crossing with laboratory strain K-12. Infect. Immun. 64:3218-3223.

Bolstad, B. M., Irizarry, R. A., Astrand, M., and Speed, T. P. 2003. A comparison of normalization methods for high density oligonucleotide array data based on variance and bias. Bioinformatics 19:185-193.

Broughton, W. T., and Dilworth, M. J. 1971. Control of leghaemoglobin synthesis in snake beans. Biochem. J. 125:1075-1080.

Cabanes, D., Dussurget, O., Dehoux, P., and Cossart, P. 2004. Auto, a surface associated autolysin of Listeria monocytogenes required for entry into eukaryotic cells and virulence. Mol Microbiol 51:1601-1614.

Campbell, G. R., Reuhs, B. L., and Walker, G. C. 2002. Chronic intracel- 
lular infection of alfalfa nodules by Sinorhizobium meliloti requires correct lipopolysaccharide core. Proc. Natl. Acad. Sci. U.S.A. 99:39383943.

Capela, D., Filipe, C., Bobik, C., Batut, J., and Bruand, C. 2006. Sinorhizobium meliloti differentiation during symbiosis with alfalfa: A transcriptomic dissection. Mol. Plant-Microbe Interact. 19:363-372.

Ceremonie, H., Debelle, F., and Fernandez, M. P. 1999. Structural and functional comparison of Frankia root hair deforming factor and rhizobia Nod factor. Can. J. Bot. 77:1293-1301.

Ceremonie, H., Cournoyer, B., Maillet, F., Normand, P., and Fernandez, M. P. 1998. Genetic complementation of rhizobial nod mutants with Frankia DNA: Artifact or reality? Mol. Gen. Genet. 260:115-119.

Chang, W.-S., Franck, W. L., Cytryn, E., Jeong, S., Joshi, T., Emerich, D. W., Sadowsky, M. J., Xu, D., and Stacey, G. 2007. An oligonucleotide microarray resource for transcriptional profiling of Bradyrhizobium japonicum. Mol. Plant-Microbe Interact. 20:1298-1307.

Claros, M. C., Claros, Z. C., Hecht, D. W., Citron, D. M., Goldstein, E. J., Silva, J., Jr., Tang-Feldman, Y., and Rodloff, A. C. 2006. Characterization of the Bacteroides fragilis pathogenicity island in human blood culture isolates. Anaerobe 12:17-22.

Cooper, J. B., and Long, S. R. 1994. Morphogenetic rescue of Rhizobium meliloti nodulation mutants by trans-zeatin secretion. Plant Cell 6:215225.

Denu, J. M., and Dixon, J. E. 1998. Protein tyrosine phosphatases: Mechanisms of catalysis and regulation. Curr. Opin. Chem. Biol. 2:633-641.

Egland, P. G., and Harwood, C. S. 1999. BadR, a new MarR family member, regulates anaerobic benzoate degradation by Rhodopseudomonas palustris in concert with AadR, an Fnr family member. J. Bacteriol. 181:2102-2109.

Galibert, F., Finan, T. M., Long, S. R., Puhler, A., Abola, P., Ampe, F., Barloy-Hubler, F., Barnett, M. J., Becker, A., Boistard, P., Bothe, G., Boutry, M., Bowser, L., Buhrmester, J., Cadieu, E., Capela, D., Chain, P., Cowie, A., Davis, R. W., Dreano, S., Federspiel, N. A., Fisher, R. F., Gloux, S., Godrie, T., Goffeau, A., Golding, B., Gouzy, J., Gurjal, M., Hernandez-Lucas, I., Hong, A., Huizar, L., Hyman, R. W., Jones, T., Kahn, D., Kahn, M. L., Kalman, S., Keating, D. H., Kiss, E., Komp, C., Lelaure, V., Masuy, D., Palm, C., Peck, M. C., Pohl, T. M., Portetelle, D., Purnelle, B., Ramsperger, U., Surzycki, R., Thebault, P., Vandenbol, M., Vorholter, F. J., Weidner, S., Wells, D. H., Wong, K., Yeh, K. C., and Batut, J. 2001. The composite genome of the legume symbiont Sinorhizobium meliloti. Science 293:668-672.

Gherbi, H., Markmann, K., Svistoonoff, S., Estevan, J., Autran, D., Giczey, G., Auguy, F., Peret, B., Laplaze, L., Franche, C., Parniske, M., and Bogusz, D. 2008. SymRK defines a common genetic basis for plant root endosymbioses with arbuscular mycorrhiza fungi, rhizobia, and Frankia bacteria. Proc. Natl. Acad. Sci. U.S.A. 105:4928-4932.

Giraud, E., Moulin, L., Vallenet, D., Barbe, V., Cytryn, E., Avarre, J. C., Jaubert, M., Simon, D., Cartieaux, F., Prin, Y., Bena, G., Hannibal, L., Fardoux, J., Kojadinovic, M., Vuillet, L., Lajus, A., Cruveiller, S., Rouy, Z., Mangenot, S., Segurens, B., Dossat, C., Franck, W. L., Chang, W. S., Saunders, E., Bruce, D., Richardson, P., Normand, P., Dreyfus, B., Pignol, D., Stacey, G., Emerich, D., Vermeglio, A., Medigue, C., and Sadowsky, M. 2007. Legumes symbioses: Absence of Nod genes in photosynthetic bradyrhizobia. Science 316:1307-1312.

Gomez, J. E., and Bishai, W. R. 2000. whmD is an essential mycobacterial gene required for proper septation and cell division. Proc. Natl. Acad. Sci. U.S.A. 97:8554-8559.

Gonzalez, J. E., Reuhs, B. L., and Walker, G. C. 1996. Low molecular weight EPS II of Rhizobium meliloti allows nodule invasion in Medicago sativa. Proc. Natl. Acad. Sci. U.S.A. 93:8636-8641.

Gonzalez, V., Bustos, P., Ramirez-Romero, M. A., Medrano-Soto, A., Salgado, H., Hernandez-Gonzalez, I., Hernandez-Celis, J. C., Quintero, V., Moreno-Hagelsieb, G., Girard, L., Rodriguez, O., Flores, M. Cevallos, M. A., Collado-Vides, J., Romero, D., and Davila, G. 2003. The mosaic structure of the symbiotic plasmid of Rhizobium etli CFN42 and its relation to other symbiotic genome compartments. Genome Biol. 4:R36.

Gottfert, M., Rothlisberger, S., Kundig, C., Beck, C., Marty, R., and Hennecke, H. 2001. Potential symbiosis-specific genes uncovered by sequencing a 410-kilobase DNA region of the Bradyrhizobium japonicum chromosome. J. Bacteriol. 183:1405-1412.

Guan, C., Ribeiro, A., Akkermans, A. D., Jing, Y., van Kammen, A., Bisseling, T., and Pawlowski, K. 1996. Nitrogen metabolism in actinorhizal nodules of Alnus glutinosa: Expression of glutamine synthetase and acetylornithine transaminase. Plant Mol. Biol. 32:1177-1184.

Hammad, Y., Maréchal, J., Cournoyer, B., Normand, P., and Domenach, A. M. 2001. Modification of the protein expression pattern induced in the nitrogen-fixing actinomycete Frankia sp. strain ACN14a-tsr by root exudates of its symbiotic host Alnus glutinosa and cloning of the sodF gene. Can. J. Microbiol. 47:541-547.
Hammad, Y., Nalin, R., Maréchal, J., Fiasson, K., Pepin, R., Berry, A. M. Normand, P., and Domenach, A.-M. 2003. A possible role for phenylacetic acid (PAA) in Alnus glutinosa nodulation by Frankia. Plant Soil 254:193-205.

Hauser, F., Pessi, G., Friberg, M., Weber, C., Rusca, N., Lindemann, A., Fischer, H. M., and Hennecke, H. 2007. Dissection of the Bradyrhizobium japonicum NifA+sigma54 regulon, and identification of a ferredoxin gene $(f d x N)$ for symbiotic nitrogen fixation. Mol. Genet. Genomics 278:255-271.

Hervas, A. B., Canosa, I., Little, R., Dixon, R., and Santero, E. 2009. NtrC-dependent regulatory network for nitrogen assimilation in $\mathrm{Pseu}$ domonas putida. J. Bacteriol. 191:6123-6135.

Huss-Danell, K. 1997. Actinorhizal symbioses and their N2-fixation. New Phytol. 136:375-405.

Hwang, B. K., Lim, S. W., Kim, B. S., Lee, J. Y., and Moon, S. S. 2001. Isolation and in vivo and in vitro antifungal activity of phenylacetic acid and sodium phenylacetate from Streptomyces humidus. Appl. Environ. Microbiol. 67:3739-3745.

Irizarry, R. A., Hobbs, B., Collin, F., Beazer-Barclay, Y. D., Antonellis, K. J., Scherf, U., and Speed, T. P. 2003. Exploration, normalization, and summaries of high density oligonucleotide array probe level data. Biostatistics 4:249-264.

Jeong, J., Suh, S., Guan, C., Tsay, Y. F., Moran, N., Oh, C. J., An, C. S., Demchenko, K. N., Pawlowski, K., and Lee, Y. 2004. A nodule-specific dicarboxylate transporter from alder is a member of the peptide transporter family. Plant Physiol. 134:969-978.

Juty, N. S., Moshiri, F., Merrick, M., Anthony, C., and Hill, S. 1997. The Klebsiella pneumoniae cytochrome bd' terminal oxidase complex and its role in microaerobic nitrogen fixation. Microbiol. 143:2673-2683.

Kadota, K., Nakai, Y., and Shimizu, K. 2008. A weighted average difference method for detecting differentially expressed genes from microarray data. Algorithms Mol. Biol. 3:8.

Kambara, K., Ardissone, S., Kobayashi, H., Saad, M. M., Schumpp, O. Broughton, W. J., and Deakin, W. J. 2009. Rhizobia utilize pathogenlike effector proteins during symbiosis. Mol. Microbiol. 71:92-106.

Kaneko, T., Nakamura, Y., Sato, S., Minamisawa, K., Uchiumi, T., Sasamoto, S., Watanabe, A., Idesawa, K., Iriguchi, M., Kawashima, K. Kohara, M., Matsumoto, M., Shimpo, S., Tsuruoka, H., Wada, T., Yamada, M., and Tabata, S. 2002. Complete genomic sequence of nitrogen-fixing symbiotic bacterium Bradyrhizobium japonicum USDA110. DNA Res. 9:189-197.

Kaneko, T., Nakamura, Y., Sato, S., Asamizu, E., Kato, T., Sasamoto, S., Watanabe, A., Idesawa, K., Ishikawa, A., Kawashima, K., Kimura, T., Kishida, Y., Kiyokawa, C., Kohara, M., Matsumoto, M., Matsuno, A., Mochizuki, Y., Nakayama, S., Nakazaki, N., Shimpo, S., Sugimoto, M., Takeuchi, C., Yamada, M., and Tabata, S. 2000. Complete genome structure of the nitrogen-fixing symbiotic bacterium Mesorhizobium loti. DNA Res. 7:331-338.

Kelly, M. J., Poole, R. K., Yates, M. G., and Kennedy, C. 1990. Cloning and mutagenesis of genes encoding the cytochrome bd terminal oxidase complex in Azotobacter vinelandii: Mutants deficient in the cytochrome $\mathrm{d}$ complex are unable to fix nitrogen in air. J. Bacteriol. 172:6010-6019.

Kers, J. A., Cameron, K. D., Joshi, M. V., Bukhalid, R. A., Morello, J. E., Wach, M. J., Gibson, D. M., and Loria, R. 2005. A large, mobile pathogenicity island confers plant pathogenicity on Streptomyces species. Mol. Microbiol. 55:1025-1033.

Kormanec, J., and Homerova, D. 1993. Streptomyces aureofaciens whiB gene encoding putative transcription factor essential for differentiation. Nucleic Acids Res. 21:2512.

Kucho, K., Kakoi, K., Yamaura, M., Higashi, S., Uchiumi, T., and Abe, M. 2009. Transient transformation of Frankia by fusion marker genes in liquid culture. Microbes Environ. 24:231-240.

Lee, K. B., De Backer, P., Aono, T., Liu, C. T., Suzuki, S., Suzuki, T., Kaneko, T., Yamada, M., Tabata, S., Kupfer, D. M., Najar, F. Z., Wiley, G. B., Roe, B., Binnewies, T. T., Ussery, D. W., D’Haeze, W., Herder, J. D., Gevers, D., Vereecke, D., Holsters, M., and Oyaizu, H. 2008. The genome of the versatile nitrogen fixer Azorhizobium caulinodans ORS571. BMC Genomics 9:271.

Lerouge, I., and Vanderleyden, J. 2002. O-antigen structural variation: Mechanisms and possible roles in animal/plant-microbe interactions. FEMS (Fed. Eur. Microbiol. Soc.) Microbiol. Rev. 26:17-47.

Leul, M., Normand, P., and Sellstedt, A. 2007. The organization, regulation and phylogeny of uptake hydrogenase genes in Frankia. Physiol. Plant. 130:464-470.

Leul, M., Normand, P., and Sellstedt, A. 2009. The phylogeny of uptake hydrogenases in Frankia. Int. Microbiol. 12:23-28.

Lundquist, P.-O., and Huss-Danell, K. 1991. Response of nitrogenase to altered carbon supply in a Frankia-Alnus incana symbiosis. Physiol. Plant. 83:331-338.

Markmann, K., Giczey, G., and Parniske, M. 2008. Functional adaptation 
of a plant receptor-kinase paved the way for the evolution of intracellular root symbioses with bacteria. PLoS Biol. 6:e68.

Mastronunzio, J. E., Tisa, L. S., Normand, P., and Benson, D. R. 2008 Comparative secretome analysis suggests low plant cell wall degrading capacity in Frankia symbionts. BMC Genomics 9:47.

Mavingui, P., Flores, M., Guo, X., Davila, G., Perret, X., Broughton, W. J., and Palacios, R. 2002. Dynamics of genome architecture in Rhizobium sp. strain NGR234. J. Bacteriol. 184:171-176.

Mort, A., Normand, P., and Lalonde, M. 1983. 2-O-methyl-D-mannose, a key sugar in the taxonomy of Frankia. Can. J. Microbiol. 29:993-1002.

Murry, M., Fontaine, M., and Torrey, J. 1984. Growth kinetics and nitrogenase induction in Frankia sp. HFPArI3 grown in batch culture. Plant Soil 78:61-78

Nalin, R., Putra, S. R., Domenach, A. M., Rohmer, M., Gourbiere, F., and Berry, A. M. 2000. High hopanoid/total lipids ratio in Frankia mycelia is not related to the nitrogen status. Microbiology 146:3013-3019.

Nano, F. E., Zhang, N., Cowley, S. C., Klose, K. E., Cheung, K. K., Roberts M. J., Ludu, J. S., Letendre, G. W., Meierovics, A. I., Stephens, G., and Elkins, K. L. 2004. A Francisella tularensis pathogenicity island required for intramacrophage growth. J. Bacteriol. 186:6430-6436.

Newman, J. D., Diebold, R. J., Schultz, B. W., and Noel, K. D. 1994 Infection of soybean and pea nodules by Rhizobium spp. purine auxotrophs in the presence of 5-aminoimidazole-4-carboxamide riboside. J. Bacteriol. 176:3286-3294

Normand, P., and Lalonde, M. 1982. Evaluation of Frankia strains isolated from provenances of two Alnus species. Can. J. Microbiol. 28:11331142 .

Normand, P., Queiroux, C., Tisa, L., Benson, D., Cruveiller, S., Rouy, Z., and Medigue, C. 2007a. Exploring the genomes of Frankia sp. Physiol. Plant. 13:331-343.

Normand, P., Lapierre, P., Tisa, L. S., Gogarten, J. P., Alloisio, N., Bagnarol, E., Bassi, C. A., Berry, A. M., Bickhart, D. M., Choisne, N., Couloux, A., Cournoyer, B., Cruveiller, S., Daubin, V., Demange, N., Francino, M. P., Goltsman, E., Huang, Y., Kopp, O. R., Labarre, L., Lapidus, A., Lavire, C., Maréchal, J., Martinez, M., Mastronunzio, J. E., Mullin, B. C., Niemann, J., Pujic, P., Rawnsley, T., Rouy, Z., Schenowitz, C., Sellstedt, A., Tavares, F., Tomkins, J. P., Vallenet, D., Valverde, C., Wall, L. G., Wang, Y., Medigue, C., and Benson, D. R. 2007b. Genome characteristics of facultatively symbiotic Frankia sp. strains reflect host range and host plant biogeography. Genome Res. 17:7-15.

Ott, T., van Dongen, J. T., Gunther, C., Krusell, L., Desbrosses, G., Vigeolas, H., Bock, V., Czechowski, T., Geigenberger, P., and Udvardi, M. K. 2005. Symbiotic leghemoglobins are crucial for nitrogen fixation in legume root nodules but not for general plant growth and development. Curr Biol 15:531-535.

Parada, M., Vinardell, J. M., Ollero, F. J., Hidalgo, A., Gutierrez, R., Buendia-Claveria, A. M., Lei, W., Margaret, I., Lopez-Baena, F. J., GilSerrano, A. M., Rodriguez-Carvajal, M. A., Moreno, J., and Ruiz-Sainz, J. E. 2006. Sinorhizobium fredii HH103 mutants affected in capsular polysaccharide (KPS) are impaired for nodulation with soybean and Cajanus cajan. Mol. Plant-Microbe Interact. 19:43-52.

Parsons, R., Silvester, W. B., Harris, S., Gruijters, W. T., and Bullivant, S. 1987. Frankia vesicles provide inducible and absolute oxygen protection for nitrogenase. Plant Physiol. 83:728-731.

Pawlowski, K., and Bisseling, T. 1996. Rhizobial and actinorhizal symbioses: What are the shared features? Plant Cell 8:1899-1913.

Perret, X., Broughton, W. J., and Brenner, S. 1991. Canonical ordered cosmid library of the symbiotic plasmid of Rhizobium species NGR234. Proc. Natl. Acad. Sci. U.S.A. 88:1923-1927.

Pessi, G., Ahrens, C. H., Rehrauer, H., Lindemann, A., Hauser, F., Fischer, H. M., and Hennecke, H. 2007. Genome-wide transcript analysis of Bradyrhizobium japonicum bacteroids in soybean root nodules. Mol. Plant-Microbe Interact. 20:1353-1363.

Raghavan, S., Manzanillo, P., Chan, K., Dovey, C., and Cox, J. S. 2008. Secreted transcription factor controls Mycobacterium tuberculosis virulence. Nature 454:717-721.

Santero, E., Hoover, T. R., North, A. K., Berger, D. K., Porter, S. C., and Kustu, S. 1992. Role of integration host factor in stimulating transcription from the sigma 54-dependent nifH promoter. J. Mol. Biol. 227:602620

Santos, C., Vieira, J., Normand, P., Moradas-Ferreira, P., and Tavares, F. 2007. Expression, activity and phylogeny of catalases: A global approach to Frankia alni ACN14a oxidative stress response. Physiol. Plant. 130:454-463.

Schultz, N. A., and Benson, D. R. 1990. Enzymes of ammonia assimilation in hyphae and vesicles of Frankia sp. strain CpI1. J. Bacteriol
172:1380-1384.

Schwencke, J. 1991. Rapid, exponential growth and increased biomass yield of some Frankia strains in buffered and stirred mineral medium (BAP) with phosphatidyl choline. Plant Soil 137:37-41.

Sellstedt, A., and Mattsson, U. 1994. Hydrogen metabolism in Casuarina Frankia immunolocalization of nitrogenase and hydrogenase. Soil Biol. Biochem. 26:583-592.

Soberon, M., Aguilar, G. R., and Sanchez, F. 1993. Rhizobium phaseoli cytochrome c-deficient mutant induces empty nodules on Phaseolus vulgaris L. Mol. Microbiol. 8:159-166.

Soltis, D., Soltis, P., Morgan, D., Swensen, S., Mullin, B., Dowd, J., and Martin, P. 1995. Chloroplast gene sequence data suggest a single origin of the predisposition for symbiotic nitrogen fixation in angiosperms. Proc. Natl. Acad. Sci. U.S.A. 92:2647-2651.

Stevens, G., and Berry, A. 1988. Cytokinin secretion by Frankia sp. HFPArI3 in defined medium. Plant. Physiol. 87:15-16.

Sullivan, J. T., and Ronson, C. W. 1998. Evolution of rhizobia by acquisition of a 500-kb symbiosis island that integrates into a phe-tRNA gene. Proc. Natl. Acad. Sci. U.S.A. 95:5145-5149.

Suzuki, K., Nakata, N., Bang, P. D., Ishii, N., and Makino, M. 2006. Highlevel expression of pseudogenes in Mycobacterium leprae. FEMS (Fed. Eur. Microbiol. Soc.) Microbiol. Lett. 259:208-214.

Suzuki, S., Aono, T., Lee, K. B., Suzuki, T., Liu, C. T., Miwa, H., Wakao, S., Iki, T., and Oyaizu, H. 2007. Rhizobial factors required for stem nodule maturation and maintenance in Sesbania rostrata-Azorhizobium caulinodans ORS571 symbiosis. Appl. Environ. Microbiol. 73:66506659

Tatusov, R. L., Natale, D. A., Garkavtsev, I. V., Tatusova, T. A. Shankavaram, U. T., Rao, B. S., Kiryutin, B., Galperin, M. Y., Fedorova, N. D., and Koonin, E. V. 2001. The COG database: New developments in phylogenetic classification of proteins from complete genomes. Nucleic Acids Res. 29:22-28.

Tjepkema, J., Ormerod, W., and Torrey, J. 1981. Factors affecting vesicle formation and acetylene reduction (nitrogenase activity) in Frankia sp. CpI1. Can. J. Microbiol. 27:815-823.

Tsukada, S., Aono, T., Akiba, N., Lee, K. B., Liu, C. T., Toyazaki, H., and Oyaizu, H. 2009. Comparative genome-wide transcriptional profiling of Azorhizobium caulinodans ORS571 grown under free-living and symbiotic conditions. Appl. Environ. Microbiol. 75:5037-5046.

Uchiumi, T., Ohwada, T., Itakura, M., Mitsui, H., Nukui, N., Dawadi, P. Kaneko, T., Tabata, S., Yokoyama, T., Tejima, K., Saeki, K., Omori, H., Hayashi, M., Maekawa, T., Sriprang, R., Murooka, Y., Tajima, S., Simomura, K., Nomura, M., Suzuki, A., Shimoda, Y., Sioya, K., Abe, M., and Minamisawa, K. 2004. Expression islands clustered on the Symbiosis Island of the Mesorhizobium loti genome. J. Bacteriol. 186:2439-2448.

Van Ghelue, M., Lovaas, E., Ringo, E., and Solheim, B. 1997. Early interactions between Alnus glutinosa and Frankia strain ArI3. Production and specificity of root hair deformation factor(s). Physiol. Plant. 99:579-587.

Wassem, R., De Souza, E. M., Yates, M. G., Pedrosa, F. D., and Buck, M. 2000. Two roles for integration host factor at an enhancer-dependent nifA promoter. Mol. Microbiol. 35:756-764.

Williams, D. L., Torrero, M., Wheeler, P. R., Truman, R. W., Yoder, M., Morrison, N., Bishai, W. R., and Gillis, T. P. 2004. Biological implications of Mycobacterium leprae gene expression during infection. J. Mol. Microbiol. Biotechnol. 8:58-72.

Young, J. P., Crossman, L. C., Johnston, A. W., Thomson, N. R., Ghazoui, Z. F., Hull, K. H., Wexler, M., Curson, A. R., Todd, J. D., Poole, P. S., Mauchline, T. H., East, A. K., Quail, M. A., Churcher, C., Arrowsmith, C., Cherevach, I., Chillingworth, T., Clarke, K., Cronin, A., Davis, P., Fraser, A., Hance, Z., Hauser, H., Jagels, K., Moule, S., Mungall, K., Norbertczak, H., Rabbinowitsch, E., Sanders, M., Simmonds, M., Whitehead, S., and Parkhill, J. 2006. The genome of Rhizobium leguminosarum has recognizable core and accessory components. Genome Biol. 7:R34.

\section{AUTHOR-RECOMMENDED INTERNET RESOURCES}

Kyoto Encyclopedia of Genes and Genomes (KEGG) sequence similarity database (SSDB): www.genome.jp/kegg/ssdb

Magnifying genomes microbial genome annotation system (MAGE): www.genoscope.cns.fr/agc/mage

NimbleGen Arrays User's Guide: Gene Expression Analysis (Version 3.2): www.nimblegen.com/products/lit/exp_userguide_v3p2.pdf 